\title{
Political Selection of Public Servants and Parliamentary Oversight*
}

\author{
Thomas Braendle ${ }^{\dagger}$ and Alois Stutzer ${ }^{\ddagger}$
}

October 21, 2012

\begin{abstract}
In this paper, we propose a framework to integrate the identity of legislators in a politicoeconomic analysis of parliamentary oversight. Legislators decide about the effort they invest in oversight activities depending on their individual control costs and the level of electoral competition. We focus on public servants elected to parliament who face a conflict of interests but also have lower control costs due to their experience and information advantage. If held accountable, oversight becomes a relatively attractive activity for them to win votes. For German Laender, we find that the fraction of public servants in parliament is positively related to the number of submitted parliamentary interpellations. This result holds when instrumenting the fraction of public servants in parliament with its institutional determinants. Moreover, a mixed-member electoral system as well as a tighter race between the two biggest parties is related to more, a larger number of parties in parliament to less minor interpellations.
\end{abstract}

Keywords: Political selection, parliamentary oversight, public servants, interpellations

JEL classification: D72, D73, H11, H83

${ }^{*}$ Revised version for the journal Economics of Governance. We are grateful to two anonymous referees, Tim Besley, Beat Blankart, Bruno S. Frey, Vincenzo Galasso, Martin Hellwig, Thorsten Henne, Simon Luechinger, Manuela Merki, Tommaso Nannicini, Michael Zehnder, seminar participants at Bocconi University, Max-Planck-Institute Bonn, CIRCaP University of Siena, and participants at the CLEF Annual Meeting at the Yale Law School, the Meeting of the Swiss Society of Economics and Statistics in Fribourg, and the Meeting of the European Public Choice Society in Rennes for helpful comments. Special thanks go to Laura Sochaczewski and Michaela Slotwinski for excellent research assistance. We also thank the WWZ Forum for financial support, the IGIER at Bocconi for its hospitality, and the parliamentary information services and parliamentary libraries of the German Laender for generously providing information about the parliamentary process.

${ }^{\dagger}$ University of Basel, Faculty of Business and Economics, Peter Merian-Weg 6, 4002 Basel, Switzerland. Phone: +41 (0)61 26733 63, fax: +41 (0)61 26733 40, email: thomas.braendle@unibas.ch.

$\ddagger$ University of Basel, Faculty of Business and Economics, Peter Merian-Weg 6, 4002 Basel, Switzerland. Phone: +41 (0)61 26733 61, fax: +41 (0)61 26733 40, email: alois.stutzer@unibas.ch. 


\section{Introduction}

The oversight of the government and the subordinate public service is one of the constitutional core duties of the members of parliament in a democracy. It is a key aspect of the checks and balances in a system adhering to the principle of the separation of powers. Parliamentary oversight is instituted to restrict the abuse of government authority and to maintain incentives to efficiently provide public goods and services. For its constitutional mandate, the parliament has access to various instruments, such as the power to pass the budget, the installation of committees of inquiriy and the submission of parliamentary interpellations. Even though economists and political scientists alike emphasize the importance of legislative oversight to hold governments accountable, it is more often than not abstracted from the actual parliamentary control process in scientific work. ${ }^{1}$

In this paper, we intend to contribute to a better understanding of the parliamentary oversight process in three directions. First, we explicitly study the use of parliamentary control instruments. Second, we consider parliamentary control as the result of political selection and of the institutional structure determining political competition. Third, with regard to political selection, we focus on the role of public servants as legislators in parliamentary control. ${ }^{2} \mathrm{We}$ understand political selection as the process and the result of any systematic effect of institutions on the composition of political bodies. As to parliamentary control, political selection affects the composition of the legislature in terms of its members' individual control costs and individual motivation. The two aspects are difficult to separate though. The cost of control efforts can be lower due to skills, knowledge, an information advantage or a specific motivation to control (e.g., due to public service motivation or civic duty, etc.).

We argue that the selection of public servants into legislatures is of particular interest for understanding how political selection affects parliamentary oversight. First, parliaments across the world differ widely in the fraction of (former) public servants in their compositional structure. In the United States or the United Kingdom, there are relatively few former public servants in the national parliament as they are ineligible to run for a seat. In contrast, in the legislatures of Denmark, Austria or Germany, for example, the share of public servants has often reached more than forty percent since World War II. Second, public servants might systematically differ in terms of their individual cost and motivation for parliamentary control. On the one hand,

\footnotetext{
${ }^{1}$ For our purpose, we use the terms parliamentary control, oversight, and monitoring interchangeably. For descriptions of oversight see, e.g., Rosenthal (1981) and Patzelt (2005).

${ }^{2}$ As to public servants, we include all employees that receive public pay and have a work contract under public law; i.e., for example, educational professionals such as teachers or university professors, public servants or employees in the public administration, and members of the judiciary or the police.
} 
the selection of public servants to the legislature can serve as a check. If the information asymmetry between the public service and the legislature is severe (as, e.g., pointed out by Niskanen 1971), electing insiders to parliament who become accountable to the electorate might help to align interests between principals and agents. Public servants in parliament who dispose of an information advantage with respect to public service issues and who face lower control costs enhance the monitoring competence of the elected assemblies. On the other hand, public servants in parliament compromise the principle of the (personal) separation of powers and thus face a conflict of interests. This is due to their double role as agents in public service and as principals that supervise the public service in parliament. In sum, it is an open question whether the specific motivation and individual control costs of public servants in parliament lead to more or less parliamentary oversight for a given level of political competition. The focus of our analysis refers to this latter question.

In addition, we lay out a general framework of parliamentary oversight based on the dispersed literature on this issue. This provides a theoretical rationale for a set of further determinants taken into account in the empirical analysis. While we mainly treat them as control variables, we consider them interesting as such.

We empirically study parliamentary oversight for the institutional context of Germany and its sixteen Laender (as the federal states are called). We do this for mainly two reasons: First, parliamentary control of the government and its subordinate public service is a main task of the members of parliament in the German Laender. Most new law is enacted on the federal level while the Laender have to implement and administer it. Second, members of parliament with a public sector background are a striking feature of politics in Germany. For instance in 1988, no less than 61.6 percent of the seats in parliament in Baden-Württemberg were held by public servants.

With respect to the instruments of parliamentary control, we focus on the most widespread instruments; i.e., major and minor interpellations and oral inquiries. ${ }^{3}$ By asking for detailed information and evaluations with regard to the efficient use of public funds, interpellations critically control government behavior. Information about the use of these control instruments is publicly available, subject to media attention, and individually attributable. As an illustration, we refer to the air fare scandal (Düsseldorfer Flugaffäre) of the government of North RhineWestphalia in 1998 to 2000. In February, 1998, a minor interpellation with the title "Do members of the government of North Rhine-Westphalia use company jets of the bank WestLB" was

\footnotetext{
${ }^{3}$ Depending on the legal framework and the period analyzed, preference may be given to either the term inquiry or the term interpellation. Since the economic interpretation in our context is the same, we abstract from such differences in terminology and rather use the terms interchangeably.
} 
submitted and aimed at gaining information on why, when, where to and at whose expense, members of the government (ab-)used the company jets. The unsatisfactory government reply contributed to further political and media attention and led to the appointment of a committee of inquiry investigating the issue in more detail in 1999 - 2000. Johannes Rau (President of North Rhine-Westphalia at this time and former President of Germany) admitted errors regarding the conduct in office and Heinz Schleusser (Finance Minister) resigned due to serious accusation. ${ }^{4}$ This example shows how interpellations are relevant for the political process and for constituents' evaluations of a politician's performance. We take the use of these instruments to be positively related to the strictness of parliamentary oversight.

For the empirical analysis, a unique time-series cross-sectional data set has been compiled covering three different quantitative measures of parliamentary control, spanning the period from 1946 to 2009. Additionally, we gathered data on the fraction of public servants elected to parliament and collected information on the electoral system, the form of government, alternations in (coalition) government, the ideology of government, the margin of victory in electoral races, the number of parties, the seat share of the Social Democrats, and the length of legislative periods.

We find a positive correlation between the political selection variable; i.e., the fraction of public servants in parliament, and the number of parliamentary inquiries submitted. This holds in particular for minor interpellations; i.e., the main individual control instrument for efficiency control. The result is confirmed if we apply an instrumental variable approach instrumenting the fraction of public servants in parliament with its institutional determinants. The effect of public servants on the use of minor interpellations seems thereby driven by variation at the beginning of our observation period and to attenuate in later years. Consistent with our aggregate findings is qualitative evidence from in-depth analyses of individual-level behavior of public servants during parliamentary debates by Schrode (1977). He reports that public servants are more active and more critical regarding government behavior in the parliamentary process than members from other sectors. This is especially the case in public service matters. In addition, we find a generally positive level effect of a mixed-member electoral system on the number of parliamentary inquiries. This effect is, however, identified based on institutional reforms in only three Laender. In mixed-member electoral systems a fraction of the legislature is elected through a majoritarian procedure (rather than through a proportional procedure). A majoritarian procedure is understood to increase political competition as individual candidates can be held accountable by the electorate.

\footnotetext{
${ }^{4}$ The minor interpellation was submitted on February 17, 1998 (parliamentary printed matter 12/2886) and the government replied on April 6, 1998 (parliamentary printed matter 12/2997). Reporting on the air fare scandal was in all major German newspapers such as the Frankfurter Allgemeine Zeitung, the Süddeutsche Zeitung, Spiegel, and Fokus.
} 
This study contributes to the research on political selection and on the comparative institutional analysis of parliamentary control. With regard to the former aspect, related recent empirical and theoretical work has been conducted by researchers such as Besley (2005), Braendle and Stutzer (2011), Caselli and Morelli (2004), Chattopadhyay and Duflo (2004), Gagliarducci et al. (2010), Gagliarducci and Nannicini (2012), Galasso and Nannicini (2011), and van Aaken and Voigt (2011). As to parliamentary oversight, this is related to the (often US-specific) analysis of oversight relationships and bargaining processes between the bureaucracy and the legislator (Banks and Weingast 1992, Calvert et al. 1989, Moe 1989, Niskanen 1971, 1975, Ogul and Rockman 1990, Rosenthal 1981, Weingast and Moran 1983), the (legislative) design of administrative procedures and ex ante control (Bawn 1995, 1997 and McCubbins et al. 1987), and the separation of powers (Persson et al. 1997, Grossman and Helpman 2008). Our analysis also contributes to the limited body of research on the effectiveness of legislators (Grant and Kelly 2008, Padro i Miquel and Snyder 2006 and Shiller 1995), and the German political science literature dealing with state legislatures and governmental-parliamentary relationships (Holtmann and Patzelt 2004, Patzelt 2005).

Section 2 presents the main theoretical arguments about the incentives for parliamentary control with a focus on public servants elected to parliament. Section 3 deals with the German institutional background. In Section 4, the data sets and the econometric analysis are presented. Section 5 offers concluding remarks.

\section{Theoretical Considerations}

The institutional structure shapes the incentives of the members of parliament to execute parliamentary oversight. Differences in motivations and skills influence their ability and individual costs to effectively control the executive bodies. In this section, we, first, briefly explain the importance of parliamentary oversight for the democratic process. Second, we discuss politicians' incentives, trade-offs and individual costs when deciding about resources to invest in parliamentary control. This framework is, third, extended to the case of parliamentarians with a public service background. We consider occupational background as an important determinant of economic interests and control costs. Fourth, we take into account additional factors affecting parliamentary oversight.

\subsection{Relevance of Parliamentary Oversight}

A major constitutional principle in a democracy is the separation of powers sustained by a set of checks and balances. One primary check that falls within the responsibility of the legislature 
is the control of the government on behalf of the citizens. The oversight function implies first and foremost the prevention, the detection and the restriction of discretionary executive abuse. Second, oversight is meant to ensure that policies announced by the government and authorized by parliament are properly implemented. This involves an efficiency control. Finally, oversight involves the critical examination of government proposals. This is often referred to as political control with respect to the (partisan) direction in which policies are developed. Overall, there is the constitutional idea that parliamentary control of the government being institutionalized by a set of parliamentary oversight instruments ensures a responsive government and thus an efficient provision of services by the subordinate public agencies.

\subsection{Incentives for Parliamentary Oversight}

There are several arguments why legislators have at best moderate incentives to strictly control government behavior despite their constitutional mandate. First, strict oversight has a strong public good dimension within the legislature. Monitoring benefits the whole population and rarely favors single districts or narrowly targeted groups so that it would become individually attractive (e.g., Weingast 1984). Second, monitoring is largely ineffective because the public ministerial administration has a clear informational advantage regarding the costs of producing public services (Niskanen 1971). In particular, the lack of organizational structure and staff resources (Rosenthal 1981) as well as the longer time horizon of public ministerial agencies create a situation where the administration dominates parliament rather than being seriously supervised by it. Moreover, parliamentary attention tends to be sporadic and is often motivated by some scandal calling for control only subsequent to the event (Weingast 1984).

However, there are also incentives encouraging parliamentary oversight. This is taken as selfevident in the literature on the congressional dominance model (e.g., Calvert et al. 1989, Banks 1989, and Ferejohn and Krehbiel 1987). Politicians can spend time on campaigning, legislating, services to district constituents, earning outside income and oversight. ${ }^{5}$ For politicians with the relevant political expertise, oversight is an activity that helps them to distinguish themselves from other politicians in the competition for votes. Oversight expertise is acquired during a political career and in previous or current professions. Monitoring is further stimulated by media coverage since it is pursued to attract public attention and to increase one's reputation. Stricter oversight is also expected if the (local) constituency complains about the public provision of goods and services. Constituents reduce the information costs of monitoring by reporting to

\footnotetext{
${ }^{5}$ For a discussion about outside earnings and absenteeism, see Gagliarducci et al. (2010), for a discussion of outside earnings and electoral competition, see Becker et al. (2009), and for a comprehensive overview about politicians' outside earnings see Diermeier et al. (2005) for the US Congress and Merlo et al. (2010) for the Italian parliament.
} 
their representatives. This is particularly relevant if there are well organized interest groups in the politician's district that have sufficient resources and strong incentives to keep a watchful eye on public service behavior (Banks and Weingast 1992).

Several of the previous arguments hint at the role of political competition in shaping the individual politician's cost-benefit calculus. If competitive pressure is stronger, politicians are expected to engage more often in oversight activities.

It is self-evident that the different arguments are more or less relevant for individual politicians in shaping their incentives to engage in parliamentary oversight, the individual control costs being of particular importance. Legislators with better knowledge about the functioning of the public service and better access to information about the provision of public goods and public services have relatively lower costs for engaging in parliamentary control.

\subsection{Public Servants as Legislators}

Public servants in comparison to legislators from the private sector represent a selection of people in parliament who differ in their incentives, costs and maybe even in their intrinsic motivation for engaging in parliamentary control.

\section{Cost advantage in parliamentary oversight}

Information asymmetries between the public service and the legislature are an obstacle to parliamentary oversight. Electing public servants with a high degree of expertise in public service issues to parliament is expected to attenuate this situation. A first informational advantage in public service issues consists of specific knowledge about the proper execution of a public servant's (previous) function. A second component refers to knowledge about the general functioning of the public service as a whole. This involves familiarity with the efficiency control executed by the public employer and ultimately by the parliament. It also includes knowledge about the legal status of public servants; i.e., civil service salary law, civil service career law, and public services law as well as legal and administrative procedures in general. ${ }^{6}$ Representatives with a public service background can thus execute parliamentary control at comparatively lower costs. Accordingly, engaging in oversight is relatively attractive for them to promote their reputation and thus to finally win votes. For example, a parliamentarian with a public service background is more receptive to his or her constituents' complaints about the behavior of (local) public agencies. An informational advantage, first, ensures that the costs of becoming informed about local public service nuisances are relatively low. Second, the costs of bringing an issue to

\footnotetext{
${ }^{6}$ Please note that there are, of course, substantial differences with respect to (former) public servants' knowledge of administrative matters depending on their branch, function and position within the public service.
} 
parliament by means of parliamentary control instruments (e.g., interpellations) are relatively low, as well. A final argument refers to fiduciary duty. It states that a career in public service (partially) reflects public service motivation (Frank and Lewis 2004, Le Grand 2003). If such motivation carries over to behavior in political office, it contributes to a continuous monitoring of government behavior. ${ }^{7}$

\section{Conflict of interest in parliamentary oversight}

Public servants face a conflict of interest due to their double role in public service and in parliament. This compromises the personal separation of powers. A large proportion of public servants in parliament may be interpreted as embodying a strong and direct representation of public service interests. As a consequence, the public service enjoys more discretion, which prejudices the efficient provision of public services. The private interests of public servants lead to slack that is less forcefully counteracted by legislative control when the latter is pursued by committees that largely consist of public servants. ${ }^{8}$ This conflict of interest counteracts the cost advantage in monitoring.

However, other conflicts of interest might be weaker. Public servants in parliament often enjoy guaranteed reemployment and favorable terms for leave of absence with respect to time and pay. These institutional privileges render them relatively more independent of special interests. Other parliamentarians (e.g., employees of large firms, representatives of trade unions or professional associations and secretaries of parties) may encounter similar or even more favorable conditions while holding a mandate. However, they have no legal rights to reclaim the conditions; they depend on the discretion of their (former) superiors and may be bound to a direct equivalent in terms of interest representation. In contrast to other members of parliament, public servants can be considered relatively independent from outside pressure and free to dedicate themselves to parliamentary duties until the end of their political mandate.

\subsection{Additional Determinants of Parliamentary Oversight}

\section{Electoral systems and individual accountability}

A majority voting system and a mixed-member electoral system, where at least some members of parliament are elected on single seats, provide incentives for individual politicians to distinguish themselves from other parliamentarians or potential competitors and to build up their reputation as dutiful members of parliament. Accordingly, more frequent use of parliamentary control

\footnotetext{
${ }^{7}$ A fiduciary model of politicians' behavior is proposed in Besley (2006).

${ }^{8}$ However, it might be argued that a coordinated behavior of public servants in parliament is difficult to implement given the heterogeneity of public servants with respect to party affiliation, branch, function and position within the public service.
} 
instruments is expected relative to a pure proportional electoral system.

\section{Political Parties}

Parties and their parliamentary representation, the factions, often have a constitutional duty to monitor and actively criticize government behavior. Compared to individual legislators, parties have a longer time horizon (Alesina and Spear 1988). This enhances their interest in sustained oversight activity. Party leaders provide internal rewards and sanctions to induce individual members of parliament to engage in oversight (Niskanen 1975). Moreover, (large) parties can specialize internally (Snyder and Ting 2002) to organize parliamentary control and accumulate monitoring specific human capital. Whether or not parties are formally allowed to initiate parliamentary instruments, they can strategically coordinate the use of these individual tools to put pressure on the executive body.

The extent to which parties engage in parliamentary oversight is affected by the degree of party competition. The closer electoral races are expected to be, the stronger are the incentives to engage in oversight.

Related arguments refer to the new parties and the number of parties in parliament and their role in oversight. First, new parties have to distinguish themselves from the other parties and need to become known (Kalke and Raschke 2004). Second, new parties are often elected because of dissatisfaction with the government or with the parties in power. For both reasons, parliamentarians from new parties are expected to use parliamentary control instruments more frequently to actively control government behavior than established parties.

Furthermore, the number of parties might reflect the diversity of social interests represented in parliament. More diversity might be another force that stimulates the execution of oversight. However, the free rider problem in parliamentary oversight is also more severe with a larger number of parties (as there is less possibility to attribute political failures to individual actors and parties).

One might finally conjecture that the ideological composition of parliaments is related to the engagement in parliamentary control. Anticipating the empirical analysis below, this aspect creates a statistical problem if a systematic relationship between the ideological and the professional composition of parliaments exists. So it is often reported that the fraction of public servants is higher in the center-left parties. ${ }^{9}$ We take this into account statistically by including information on the party composition of parliament.

\section{Form of government}

\footnotetext{
${ }^{9}$ For the German federal parliament see; e.g., Kintz (2010) who reports a higher share of public servants in the Social Democratic Party (SPD).
} 
Parliamentary democracies experience governments that are formed by a single party as well as coalition governments. These different constellations give rise to a large set of strategic considerations when deciding about parliamentary control activity. It is argued that members of the majority party or coalition parties have little incentive to effectively control their own governmental representatives. According to this argument, the larger the majority or the coalition is, the less frequently parliamentary control instruments are used. However, the constituency of the governing majority, for the most part, holds its representatives responsible for the provision of public goods, who thus have an incentive to control the efficient provision of public services and to use the respective instruments. This might be particularly hold for political parties for which the public provision of goods and services is programatic.

It might further be argued that parties in opposition have stronger incentives to execute monitoring when they can distinguish themselves from a large fraction of representatives; e.g., in situations with coalitions of major parties. Moreover, within coalitions of major parties, oversight incentives might be strengthened as these coalitions cover a large ideological spectrum. Since such constellations are not considered to be permanent, major parties want to signal their independence by controlling the government, respectively the government representatives of the coalition partner. In addition, (coalition) governments that formed after an alternation from center-left to center-right or vice versa might experience a more contested legislative period and thus more submissions of interpellations. Summing up, no clear theoretical prediction is possible about how any one form of government is related to the overall level of parliamentary oversight.

\section{Other factors}

Some use of parliamentary oversight instruments must be seen as an expression of parliamentary activism (see, e.g., Andeweg and Irwin 1993) not primarily intended to control the government. Specific factors driving parliamentary activism are not investigated. However, we expect any statistical relationship to be weaker in later periods when media-guided parliamentary activism is stronger. Level effects are expected from larger legislatures and longer legislative periods. Parliaments entrusted with designing the constitution and establishing the most fundamental institutions might concentrate on legislating. The necessary implementation of new law might, however, also provoke more parliamentary oversight.

\section{Institutional Background}

The theoretical arguments are studied for public servants elected to German Laender parliaments. ${ }^{10}$ In Germany, the core competencies of the Laender mostly concern public service

\footnotetext{
${ }^{10}$ The public service in Germany includes all employees that receive public pay and have a work contract under public law. We are aware that there are differences in the legal status
} 
issues, such as education, cultural affairs, administrative law, police law, and municipal law. An important competence is also the actual formation of the implementation rules of federal laws (Ausführungsbestimmungen). The latter aspect implies that most sovereign duties are executed by the public service of the Laender or local authorities. Both of these are subject to the supervision of Laender parliaments. In fact, most of the time and resources of the parliamentary process at the Laender level (and significantly more than at the federal level) are devoted to controlling government behavior rather than to legislating (Patzelt 2006).

Parliamentarians in the German Laender have access to different instruments to pursue their oversight mandate in order to hold the government accountable. The major means for obtaining information and for controlling government and public-service behavior are the power to pass the budget (Budgethoheit), the institution of committees of inquiry and parliamentary interpellation rights. ${ }^{11}$ Some of these instruments are stipulated in the constitution. More commonly, they are part of the rules that govern parliamentary procedures.

We focus on the parliamentary instruments of inquiry or interpellation. Parliamentary inquiries oblige the executive body to provide the information or explanation requested (Article 20, paragraph 2, of the German constitution) and follow a strict enforcement laid down in the procedural rules. This includes access to documentations, unsolicited assistance, ministerial reports, and written comments. In addition, government declarations have to accommodate parliamentary control matters (Reutter 2008). ${ }^{12}$

The German parliaments generally allow three types of parliamentary inquiry: major and minor interpellations and oral inquiries. Box A.1 in the Appendix provides procedural details for their application highlighting the enforcement mechanism if the executive body does not react between the different occupational (sub)categories of the public service (i.e., public servants (Beamte) or employees in the public service (Angestellte im öffentlichen Dienst). However, for the scope of our analysis, there are no important differences regarding the conditions to run for parliament or the conditions of guaranteed reemployment after the termination of a mandate. Professionals from the public service, typically represented in parliaments, come from professions in education (i.e., teachers or university professors), are police officials, magistrates, ministers, political public servants, (senior-) officials in various fields of public administration, mayors and district administrators (Landräte) or employees of public enterprises. Privatizations, such as the major privatizations in the 1990s of Deutsche Post and Deutsche Telekom are taken into account. In 2005, the fraction of public servants in the working population amounted to $13.3 \%$.

${ }^{11}$ Further institutions to control government behavior include the right to demand the attendance of members of the government (Ministerzitierung), public auditing institutions (Rechnungshöfe), specialized offices of ombudspersons (e.g., the commissioner for the armed forces), petition committees, and the judicial review (Normenkontrollklage) before the German constitutional court. For an overview of the German institutional framwork see Schindler (1999). For a comparative survey on oversight instruments in national parliaments see Yamamoto (2007).

${ }^{12}$ For a discussion of parliamentary interpellation instruments see Russo and Wiberg (2010). 
according to the procedural rules. Major and minor interpellations focus on the effective use of public funds. While major interpellations address issues of broader coverage and contain questions reaching from constitutional concerns to government's intentions regarding possible reforms, minor interpellations aim at narrower issues. They form the classical tool for efficiency control. Parliamentarians use interpellations to collect information and to demand explanations, justifications and assessments of the conditions that prevail in the various fields of public service activity. Moreover, interpellations often deal with the impact of reforms and demand the government to thoroughly clarify its stance on the measures taken. Apart from questions that critically examine executive behavior, interpellations also include questions aiming at governments' intended policy actions. Typical areas of concern are the judiciary, the police, education, infrastructure, and the public administration. Oral inquiries are also submitted in order to collect information and demand explanations. However, they often address current issues and matters related to news events. An example for a minor interpellation is presented in Box A.2 in the Appendix.

In sum, the procedural rules force governments to react. The enforcement mechanism serves as a threat of launching a debate or transforming an interpellation into an interpellation of higher order thereby steering media attention. All aspects affirm the role of interpellations as strong parliamentary oversight devices.

\section{Empirical Analysis}

\subsection{Data}

The empirical analysis is based on a newly collected dataset on the use of parliamentary control instruments in all the parliaments of the German Laender and city states as well as on the factors influencing parliamentary oversight. Currently, there are sixteen German states. Up to the German reunification, there were eleven states, the so-called old German Laender. The empirical analysis covers the time period since the late 1940s (with a maximum of 63 years for Bavaria and a minimum of twelve years for the new German Laender).

\section{Parliamentary instruments of inquiry}

Data on the aggregate use of interpellations and inquiries is collected from various sources. For some Laender and some time periods, descriptive studies in political science offer data. ${ }^{13}$ Additional information is from parliamentary handbooks (Volkshandbücher) and from the parliamentary online documentation systems of the Laender. They provide detailed information for

\footnotetext{
${ }^{13}$ In particular, we draw on Kalke and Raschke (2004), Mielke and Reutter (2004), Raschke and Kalke (1994), Reutter (2008), and Schäfer (2005).
} 
recent legislative periods. In order to collect information on early legislative periods, we analyze parliamentary printed matter or protocols as well as government declarations. These materials were provided by the parliamentary information services.

For the three instruments, i.e. major and minor interpellations and the oral inquiries, there is information for 152, 153 and 133 legislative periods respectively. There is no information for some early legislative periods due to data availability. Some Laender introduced oral inquiries only in later periods. We take this into account in the empirical analysis as oral inquiries are likely to have replaced some minor interpellations.

Descriptive statistics for each of the instruments is presented in Table A.1 in the Appendix. On average, the number of major interpellations submitted within a legislative period is 66.6. For minor interpellations, the average number is 1663.6, and for oral inquiries, the respective number is 545.9 .

Figure 1 illustrates the raw number of minor interpellations and oral inquiries submitted in all the German Laender parliaments over time. No systematic pattern is observed; neither over time nor across Laender.

[Figure 1 about here]

In collecting the data on the three instruments for parliamentary inquiries, we encountered some challenges. In some cases, contradictory information about the number of submitted inquiries exists. The number of minor interpellations and oral inquiries varies because some researchers and officials count only the number of inquiries that have received replies. In some sources, it is not taken into account that inquiries not replied to in time can be transformed into higher order interpellations and that an unexpected termination of a legislative period may cause unanswered inquiries. As far as we noticed such ambiguities, we clarified the observations in question with the help of the parliamentary information services.

\section{Explanatory factors}

In the main empirical analysis, we take into account a large set of factors that are theoretically related to parliamentary oversight. We describe the explanatory variables for the largest sample; i.e., for minor interpellations. Descriptive statistics and a correlation matrix are reported in Tables A.1 and A.4 in the Appendix.

o Fraction of public servants: This variable captures the percentage of parliamentarians with a previous or concurrent occupation in the public service. Data is from Braendle and Stutzer (2010) who coded the occupational type based on the information on the very last last employment before entering parliament. On average, $40.5 \%$ of the members 
of the Laender parliament have a public sector background. The fraction was lowest in Lower Saxony (1947); i.e., 10.6 \%, and highest in Baden-Württemberg (1988); i.e., 61.6\%. The descriptive statistics for the representation of public servants in German Laender parliaments are reported in Table A.2 in the Appendix.

o Mixed-member electoral system: This variable for the electoral system (based on Massicotte 2003 ) is coded 1 (0 otherwise) if some candidates are directly elected while others enter via a party list. ${ }^{14}$ The reference category is a strictly proportional electoral system. In 2010, 14 Laender apply a mixed-member electoral system. A pure proportional electoral system is applied in Saar and Bremen. Within our sample period Bavaria, Hesse and Rhineland-Palatinate have switched from a strictly proportional electoral system to one with a majoritarian component. No switches in the other direction have been observed. The relative frequency of a mixed-member electoral system in the data set is $73.9 \%$. As to the application of the electoral rules in the single German Laender, details are shown in Table A.3 in the Appendix.

o Margin of victory: Party competition is approximated by the difference in vote shares between the strongest party and the closest competitor. The average margin of victory is $11.8 \%$.

o New party: If at least one new party enters parliament in a legislative period, the variable takes value 1 ( 0 otherwise). This is the case for roughly one third of the legislative periods in our sample.

o Number of parties: This variable states the number of parties elected to each legislative periode. The average number is 3.7 .

o Seat share of the SPD: The party composition of parliaments is captured by the seat share of the Social Democratic Party in each legislative period, which is, on average, $40.8 \%$ in our data set.

\footnotetext{
${ }^{14}$ In most Laender with a mixed member electoral system, each voter has two votes, a first vote and a second vote. The first vote is directly attributed to a candidate who represents the electoral district (majority voting component). The candidate who obtains the majority of first votes in the districts is elected to parliament by a direct mandate. With the second vote, the citizens vote for the party which may then, in accordance with its share of party votes, send candidates from closed party lists to parliament. This is the proportional voting component in the electoral system. For a detailed description of the electoral system including the discussion of bonus seats (Überhangmandate), compensatory additional list seats (Ausgleichsmandate) and further differences between the Laender, see Massicotte (2003).
} 
o Coalition government by major parties: The variable for the form of government (based on Manow and Wettengel 2006) takes value 1 (0 otherwise) if the government is supported by a coalition of the major parties (CDU, Christian Democratic Party and SPD, Social Democratic Party). In $14.4 \%$ of the legislative periods, the government was composed of the two major parties.

o Constitutional parliament: Constitutional parliament is given and coded 1 (0 otherwise) if the parliament is entrusted with designing the constitution. Nine legislative assemblies are coded as constitutional parliament.

o Oral inquiries exercisable: If the instrument of oral inquiry is introduced separately and is exercisable, the variable takes value 1 ( 0 otherwise).

o Legislative period shorter than 1.5 years: If the legislative period turns out to be shorter than 1.5 years, the variable takes value 1 ( 0 otherwise).

o Legislative period between 1.5 and 3 years: The variable takes the value 1 (0 otherwise) if the legislative period turns out to last between 1.5 years and 3 years.

o Legislative period regular 5 years: If the regular legislative period lasts 5 years, the variable takes value 1 (0 otherwise).

The reference category for the last three variables is the regular 4-year legislative period. In our data set, regular 4-year legislative periods occured 105 times, regular 5-year periods occured 37 times. Early termination of legislative periods took place eleven times. Out of these eleven periods, five terminated in less than 1.5 years. The five very short legislative periods are all characterized by interim governments since potential coalition parties were not able to form a new government after elections.

Additional variables are taken into account in the robustness analysis: Indicator variables capture (i) major alternations in government from center-left to center-right or vice versa (ii) coalition governments involving any party and (iii) governments led by the SPD. Another variable measures party concentration in parliament using a Herfindahl index.

\subsection{Results}

The results are presented in several steps. We start with an overview of the partial correlations between the identified determinants and the three parliamentary control instruments. Subsequently, we focus our analysis on minor interpellations. Our theoretical considerations fit the use of this instrument best as minor interpellations are mainly applied for efficiency control of government and public service behavior. We execute several robustness checks for the baseline 
specification and then address two major empirical challenges: First, we take into account the particular (short) time-series, (small) cross-sectional data structure incorporating dynamics as proposed by Bruno (2005). Second, in order to meet concerns regarding endogeneity, we apply an instrumental variable approach.

\section{Baseline estimations}

Table 1 presents the first set of results for the full data sample including all three oversight instruments and observations from the old and the new German Laender based on the following equation:

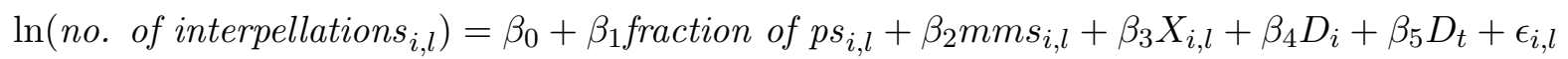

where the dependent variable is the number of submitted interpellations or inquiries in natural logarithmic terms. ${ }^{15}$ We include the fraction of public servants elected to parliament in state $i$ in legislative period $l$ as main explanatory variable. Additional explantory variables include, $m m s_{i, l}$, a dummy variable being 1 if a mixed-member electoral system is applied, and $X_{i, l}$ capturing the additional determinants identified above. Laender-fixed effects are denoted by $D_{i}$, decade-fixed effects by $D_{t}$, and $\epsilon_{i, l}$ is the error term.

Given that our dependent variable is logarithmized, we estimate specifications of a semilogarithmic functional form. Accordingly, the coefficient for a continuous variable shows the percentage change in the untransformed dependent variable per one-unit change in the explanatory factor. However, this interpretation of the estimated correlation coefficients does not hold for categorical (dummy) variables. As these coefficients are biased, we also report estimated mean coefficients (in square brackets) that are consistent, close to the unbiased results, and follow the interpretation of coefficients for continuous variables (Kennedy 1981).

There are two further general aspects concerning the specifications: First, there might be timeinvariant factors in some Laender that are not captured by our independent variables but that systematically affect the use of parliamentary control instruments. We take this unobserved Laender-specific variation into account by including Laender fixed effects in all baseline estimations. Examples for such factors might be a Laender parliament-specific political culture or simply the size of the legislature that influences the use of the different control instruments. Second, we control for unmeasured time-specific effects on the use of interpellations and inquiries that might be correlated with some of the independent variables. For instance, there might be

\footnotetext{
${ }^{15}$ If we do not transform the dependent variable, we have a count data setting. The negative skews of the three different dependent variables take values between 1.1 and 2.7 indicating only a slightly skewed shape. This does not require a model specification approach different from ordinary least squares. In our robustness checks with negative binomial models, we receive similar results.
} 
strongly disputed (political) issues in some periods that give rise to interpellations across Laender. Accordingly, we include decade fixed effects in panels II, IV and VI. We are aware that we ask a lot from the limited pool of data when we include state as well as time fixed effects. We may end up not rejecting a wrong null hypothesis; i.e. committing a type II error, in particular, due to the fact that there is common variation across Laender in the fraction of public servants over time. However, we want to clearly document the limits of our data analysis.

[Table 1 about here]

For all parliamentary control instruments, we find that a higher fraction of public servants is statistically related to more parliamentary oversight ceteris paribus. With regard to the size of the partial correlations, a one percentage point increase in the fraction of public servants in parliament is associated, on average, with a $1.4 \%$ increase in the number of major interpellations submitted (panel I). For minor interpellations, the effect is 7\% (panel III) and for oral inquiries, $2.4 \%$ respectively (panel V). These results are consistent with the hypothesis of lower individual control costs of public servants elected to parliament (given the level of political competition). The baseline estimations are, however, sensitive to the additional inclusion of time-fixed effects. For major interpellations and oral inquiries, we find that most of the variation that is related to the fraction of public servants in parliament can also be statistically accounted for by time effects (as shown in panels II and VI). For minor interpellations, the size of the partial correlations is also smaller. However, it is still sizeable and statistically significant at the $1 \%$ level (panel IV). For the further explanatory factors, we find the following partial correlations. The variable capturing a mixed-member electoral system is positively correlated with the execution of parliamentary oversight. This points in the theoretically expected direction - the more parliamentarians to be held personally accountable, the more effort is invested in parliamentary oversight. However, the coefficients have to be interpreted with caution. They are identified based on changes in the electoral system in only three German Laender. For the margin of victory, we find the theoretically expected negative sign. The larger the margin of victory is, the less engagement in oversight takes place. Legislatures with at least one new party are found to use more frequently instruments of parliamentary oversight. At least one new party in parliament is associated with $24.8 \%$ more submitted minor interpellations in panel IV. However, the partial correlations for the margin of victory as well as for new party are only statistically significant in the case of minor interpellations. For the number of parties an ambiguous picture emerges as correlations are positive for major interpellations (not statistically significant) but negative for minor interpellations and oral inquiries. No clear picture emerges also for the seat share of the SPD. The existence of a coalition government by major parties is associated with a more frequent use of all parliamentary instruments. The effects are quantitatively and statistically 
strongest for major interpellations. For the variable capturing constitutional parliaments, no statistically significant partial correlations are identified once decade fixed effects are included. However, an interpretation is difficult. With regard to the separate introduction of oral inquiries, the partial correlations indicate that there is a substitution effect of oral inquiries for minor interpellations. The length of the legislative period is statistically significantly related to the use of parliamentary control instruments. The large negative coefficient for the variable that captures the shortest legislative periods is due to the fact that all these periods are characterized by interim governments. If we standardize the dependent variable by the length of the legislative period, qualitatively and quantitatively very similar results are obtained. Together, the explanatory factors account for $64.9 \%$ of the variation in the dependent variable major interprellations, $82.3 \%$ in the variable minor interpellations and $49.1 \%$ in the variable oral inquiries when including Laender- and decade-fixed effects. The F-tests indicate that the independent variables are jointly statistically significant. ${ }^{16}$

\section{Robustness checks for the baseline estimation}

In order to assess the robustness of the results for our main instrument of interest; i.e., minor interpellations, we execute further empirical checks reported in Table A.5 in the Appendix. As baseline estimation, we take the specification in Table 1, panel IV including time- and Laender fixed effects. In a first test (panel I), we check whether alternations in government lead to more contested legislative periods and thus provoke more engagement in oversight. However, no statistically significant association is observed. A second test extends the analysis of the form of government and substitutes the variable capturing coalition government by major parties with a variable that captures any kind of coalition government (as opposed to single-party government). Again no systematic statistical relationship with oversight is estimated. As an alternative measure of party competition, we check whether the Herfindahl concentration index has an additional effect over the variable capturing the number of parties. This seems not to be

\footnotetext{
${ }^{16}$ As a further robustness check, we run the baseline estimations computing robust standard errors taking into account heteroskedasticity and serial correlation. We found qualitatively similar results. However, the calculation of robust standard errors traditionally presupposes a large number of cross-sectional units. This condition is not given in the present analysis since we only have 16 Laender. (Note though as recent contributions (see e.g., Kezdi 2004) show that the general robust standard error estimator (introduced to the fixed-effects estimator by Arellano 1987) also behaves well in finite samples.) Moreover, in our full sample the minimum number of observations per Land used to compute the disturbance of the covariance matrix is two for Mecklenburg-Lower-Pomerania and Saxony, and three for the other new German Laender. This small numerical basis renders the computation of standard errors unreliable and quite fragile. Due to these two concerns, we follow the conservative approach recommended by Angrist and Pischke (2009, chapter eight) and take whatever standard errors are larger (robust or conventional) as our measure of precision.
} 
the case though. In panel IV, we test whether there are systematic differences in the engagement in oversight under governments of different ideology. The partial correlation for governments led by the SPD is statistically not significant. For all these checks, the partial correlation for our political selection variable is unaffected.

Further estimations (not shown) address the argument of a medialization of the parliamentary process over time. This development might have generated stronger incentives for parliamentary activism, in particular, by members of the opposition parties overlaying other forces that we study here. We check the stability of the results by estimating equations based on time series of increasing length. The results indicate that the effect observed for the fraction of public servants is stronger during the early legislative periods. For the sample including elections up to $1990(\mathrm{~N}=94)$, the coefficient is $0.036(\mathrm{t}$-value=3.25) and up to 2000, the respective value is 0.034 ( $\mathrm{t}$-value $=3.77$ ) compared to a coefficient of 0.027 ( $\mathrm{t}$-value $=3.15$ ) in the full sample. In order to further explore unmeasured time-specific effects, we additionally run the same regressions with increasing length of the time-series including five-year fixed effects instead of decade fixed effects. For the sample restricted to elections up to 1990, the estimated coefficient is 0.027 ( $\mathrm{t}$-value $=2.36)$ and up to 2000 , it is 0.026 ( $\mathrm{t}$-value $=2.73)$ as compared to a coefficient of $0.020(\mathrm{t}$-value $=2.19)$ in the full sample. Overall, we observe an attenuation of the theoretically claimed relationship.

\section{Dynamic bias-corrected panel estimations}

In Table 2, we, again, concentrate on the use of minor interpellations. We restrict our analysis to the old German Laender with longer time series and address two major econometric challenges. First, dynamics are taken into account in our (short) time-series, (small) cross-sectional data set. Second, in order to meet concerns regarding endogeneity, we apply an instrumental variable approach.

[Table 2 about here]

In panels I and II, we estimate dynamic panel models that explicitly include a lagged dependent variable. We apply the least squares dummy variables estimator for dynamic panel data proposed by Bruno (2005). This estimator corrects for the small number of cross-sectional units. ${ }^{17}$ One possible driver behind a positive correlation of the residuals for consecutive legislative periods

\footnotetext{
${ }^{17}$ Nickell (1981) shows that the least squares dummy variables estimator (the common fixed effects estimator) is not consistent for finite $\mathrm{T}$ in dynamic panel data models. A number of consistent estimators, such as Arellano and Bond (1991) and Anderson and Hsiao (1982) have been proposed as alternatives to the least squares dummy variable estimator. However, the properties of the proposed estimators hold for large samples (large N) only. Bruno (2005) presents
} 
is the electoral advantage of incumbents. The average length of stay in German parliaments is about two and a half periods, see, e.g., Mielke and Reutter (2004). Accordingly, the use of parliamentary oversight is partially influenced by the inertia of the personal composition of legislatures and the oversight culture that is carried over. ${ }^{18}$

As theoretically expected, there is inertia in the use of parliamentary oversight instruments. According to specification I, the elasticity with regard to the lagged dependent variable is 0.577 . With regard to the political selection variable, the fraction of public servants in parliament is still positively related to the number of minor interpellations submitted. For a one percentage point increase, the estimated effect is between $1.2 \%$ and $2.6 \%$ and thus of an economically significant size. However, the effect is not statistically significant at conventional levels when we include decade fixed effects. This might reflect that we demand a lot (or too much) from the limited data. Another explanation might again be the attenuation over time observed and discussed above for the baseline estimations. If we apply the bias-corrected dynamic panel estimator including Laender and decade fixed effects to legislative periods with elections before $1990(\mathrm{~N}=94)$, the coefficient is $0.022(\mathrm{z}$-value=1.98), before 1995 , the respective value is 0.022 $(\mathrm{z}$-value $=2.05)$ and before 2000 , it is $0.020(\mathrm{z}$-value $=2.33)$ whereas it is $0.012(\mathrm{z}$-value $=1.42)$ in the full sample. If we further explore the stability of our results for time series of increasing length and five-year fixed effects instead of decade fixed effects, we find a similar pattern of attenuation over time. For the sample up to 1990, the coefficient is 0.019 (z-value=1.49), up to 1995 the respective value is $0.020(\mathrm{z}$-value $=1.69)$ and up to 2000 it is 0.017 (z-value=1.85) compared to 0.008 (z-value $=0.93$ ) for all observations in the old Laender. ${ }^{19}$ In sum, the air gets thin for any meaningful identification of effects and rejection of hypotheses given the available data. While the reasons for the statistically observed attenuation have to remain open, the positive relationship between the representation of public servants and minor interpellations still seems to be a relevant feature for understanding parliamentary control in Germany at least in earlier years.

\section{Instrumental variable estimations}

a bias-corrected least squares dummy variables estimator for dynamic (unbalanced) panel data models with a small number of cross-sectional units as it is the case in our empirical model. Here, the Arellano-Bond estimator is chosen to initialize the bias correction. We undertake 100 repetitions of the procedure to bootstrap the estimated standard errors. The results do neither change qualitatively with a different number of repetitions nor when we choose the AndersonHsiao estimator to initialize the bias correction.

${ }^{18}$ Since the variable covering constitutional parliaments always coincides with the first observation in a Laender-time series, it is dropped in the first and second specification.

${ }^{19}$ Additionally separating a sample for elections up to 2005 is not meaningful as the number of observations differs only by one completed legislative period compared to the full sample. 
In panels III and IV, we apply an instrumental variable approach to address concerns regarding endogeneity. This allows for the possibility that a third variable drives the fraction of public servants in parliament as well as oversight activities and thus generates a spurious correlation between the two variables. For example, a political scandal may increase voters' demand for parliamentary oversight, and simultaneously voters may also elect more public servants as legislators. To allow a consistent estimation, we instrument the fraction of public servants with the respective institutional determinants that are not themselves explanatory variables for parliamentary oversight. These instruments are taken form Braendle and Stutzer (2010). Braendle and Stutzer (2010) analyze the selection effects of institutional restrictions and privileges that apply only to public servants elected to parliament. Examples are the varying degrees in the strictness of incompatibility rules or privileges, such as special pension benefits, automatic promotion and the abeyance compensation for being put on leave. These institutions are theoretically as well as empirically strong predictors of the variation in the representation of public servants in politics. ${ }^{20}$ Panels III and IV report the results of the second stage of the two-stage least-squares estimation without and with decade fixed effects. For IV-estimates, we calculate robust standard errors taking into account panel heteroskedasticity and serial correlation. ${ }^{21}$ The fraction of public servants is again statistically significantly related to a more frequent use of minor interpellations in both panels. For the other political variables, the two econometric refinements do not change the results qualitatively. For the variable capturing the mixed-member electoral system, a positive partial correlation is found throughout.

Altogether, we find positive effects of the fraction on public servants as well as the mixed-member electoral system on the use of minor interpellations. Robustness checks reveal, however, that the effect of public servants on the use of minor interpellations is driven by variation at the beginning of our observation period and that there is an attenuation of the effect size (and the statistical significance) when we include observations after 1990. Regarding the electoral rule, the effect has to be interpreted with caution as it is identified based on institutional changes

\footnotetext{
${ }^{20}$ The result of the first-stage estimation for the instruments for the fraction of public servants is as follows: $-0.076 \mathrm{x}$ strict incompatibility $(0.035)+-0.061 \mathrm{x}$ soft incompatibility $(0.037)+$ $0.069 \mathrm{x}$ strict incompatibility $\mathrm{x}$ fulltime parliament $(0.027)+0.036 \mathrm{x}$ pension benefit $(0.021)$ $+0.084 \mathrm{x}$ abeyance compensation $(0.024)+0.069 \mathrm{x}$ automatic promotion $(0.036)+-0.055 \mathrm{x}$ other privileges $(0.023)$. The results for the further variables in the first stage are as follows: $0.045 \mathrm{x}$ mixed member electoral system $(0.031)+0.001$ margin of victory $(0.001)+0.013$ new party $(0.008)+0.006$ number of parties $(0.009)+0.002$ seat share of the SPD $(0.001)+0.006$ coalition government by major parties $(0.02)+0.026$ constitutional parliament $(0.067)+0.022$ oral inquiries exercisable (0.034). The coefficients for the indicators of the length of the legislative period as well as for the fixed effects are not reported. The F-statistic of the first-stage regression is 15.90 .

${ }^{21}$ Excluding the new German Laender alleviates the problem of having too few observations in one panel in order to reasonably compute the disturbance of the covariance matrix.
} 
in only three Laender. The margin of victory, the number of parties as well as the seat share of the SPD are negatively correlated, new parties and coalition governments by major parties positively related to the submission of minor interpellations.

Ecological fallacy and qualitative evidence on the behavior of public servants in parliament

Our theoretical analysis focuses on individual incentives while our empirical analysis has to rely on aggregate data. The standard ecological fallacy issue emerges. Knowing about the risk of misinterpretation of correlations with aggregate data, we, first, carefully studied many alternative explanations for engagement in parliamentary oversight. In particular, we include a large number of control variables in order to deal with potentially confounding factors that lead to spurious correlations.

Second, we offer qualitative individual-level evidence refering to the work by Schrode (1977). This study is the only previous investigation analyzing the behavior of public servants in parliament. Schrode himself attended parliamentary commission sittings (being non-public) and public plenary debates in the German Laender parliaments of Baden-Württemberg, Hesse and Rhineland-Palatinate. He studies the behavior of parliamentarians with a public sector background as compared to parliamentarians with other professional backgrounds in the plenary phase. He concludes that these parliamentarians are more active and more critical in commenting and controlling government behavior and that this is especially the case in public service issues. He also states that the plenary phase mirrors the behavior in the non-public committee sittings. We take this in-depth qualitative analysis as consistent and supportive of our aggregate evidence on the relationship between the selection of public servants into poltics and parliamentary oversight.

\section{Concluding Remarks}

In this paper, we propose a framework to integrate the identity of legislators in a politicoeconomic analysis of parliamentary oversight. Legislators decide about the effort they invest in oversight activities depending on their individual control costs and the level of electoral competition. More parliamentary oversight is expected if the political process selects legislators with low control costs given the competition in the political market. Identity is thus understood as heterogeneity in control costs, which is driven by processes of political selection. This approach suggests that there is an interaction of institutions that shape legislators' accountability to oversee the executive branch and institutions that affect the selection of citizens into parliaments. Our focus is on the political selection of public servants into parliament. In many countries, there is a debate about dual employment of federal and state legislators (see, e.g., Kerns and Martel 2008 for the U.S.). In particular, there are two countervailing arguments. On the one 
hand, public servants in parliament dispose of a high degree of expertise in public service issues and thus have lower individual costs of engaging in monitoring. Facing reelection incentives and individual accountability, public servants in parliament can serve as a check attenuating the information asymmetry between the executive and legislative branches of government. On the other hand, their double role as agents in the public service and as principals that supervise the public service in parliament generates a conflict of interest compromising their incentives for parliamentary oversight despite any cost advantage.

Our empirical findings for the German Laender parliaments support the hypothesis of a monitoring advantage of public servants. We find that overall a larger fraction of public servants in parliament is statistically associated with a higher number of submitted minor interpellations (our theoretically preferred indicator for parliamentary oversight). This holds when taking into account dynamics in the data as well as instrumenting the fraction of public servants in parliament with its institutional determinants. The average effect of public servants on the use of minor interpellations is thereby driven by variation at the beginning of our observation period. Consistent with our aggregate findings is qualitative evidence from an in-depth analysis of individual-level behavior of public servants during parliamentary debates by Schrode (1977). He reports that public servants are more active and more critical regarding government behavior in the parliamentary process than members from other sectors. Moreover, we find a generally positive level effect of the mixed-member electoral system on the number of submitted parliamentary inquiries which is, however, identified based on institutional reforms in only three Laender. Political competition affects parliamentary control in a differentiated way. While a tighter race between the two biggest parties in parliament is related to more interpellations, a larger number of parties as such is related to less minor interpellations.

Based on our results, we think that it is worthwhile to study explicitly the use of oversight instruments in order to gain insights into the actual process of parliamentary control. Further research might address whether there are electoral cycles in the execution of the various control instruments and if yes, whether they depend on the quality characteristics of the politicians. Beyond that, the current line of argument could be extended to outcomes of the political process. Altogether, the insights should provide a better understanding of when policy outcomes are more the result of political selection or the result of holding politicians accountable, and of when both mechanisms systematically interact. 


\section{References}

Aberbach, Joel D. (1990). Keeping a Watchful Eye. The Politics of Congressional Oversight. Washington, D.C.: Brookings Institution.

Alesina, Alberto and Stephen Spear (1988). An Overlapping Generations Model of Electoral Competition. Journal of Public Economics 37(3): 359-379.

Anderson, Theodore W. and Cheng Hsiao (1982). Formulation and Estimation of Dynamic Models Using Panel Data. Journal of Econometrics 18(1): 47-82.

Andeweg, Rudy B. and Galen A. Irwin (1993). Dutch Government and Politics. Comparative Government and Politics. Basingstoke: Macmillan.

Angrist, Joshua D. and Jörn-Steffen Pischke (2008). Mostly Harmless Econometrics. An Empiricist's Companion. Princeton: Princeton University Press.

Arellano, Manuel (1987). Computing Robust Standard Errors for Within-Groups Estimators. Oxford Bulletin of Economics and Statistics 49(4): 431-434.

Arellano, Manuel and Stephen Bond (1991). Some Tests of Specification for Panel Data: Monte Carlo Evidence and an Application to Employment Equations. Review of Economic Studies 58(2): 227-297.

Banks, Jeffrey S. (1989). Agency Budgets, Cost Information, and Auditing. American Political Science Review 33(3): 670-699.

Banks, Jeffrey S. and Barry R. Weingast (1992). The Political Control of Bureaucracies under Asymmetric Information. American Political Science Review 36(2): 509-524.

Bawn, Kathleen (1995). Political Control Versus Expertise: Congressional Choices about Administrative Procedures. American Political Science Review 89(1): 62-73.

Bawn, Kathleen (1997). Choosing Strategies to Control the Government. Statutory Constraints, Oversight, and the Committee System. Journal of Law, Economics, and Organization 13(1): 101-126.

Becker, Johannes, Andreas Peichl and Johannes Rincke (2009). Politicians' Outside Earnings and Electoral Competition. Public Choice 140(3-4): 379-394.

Besley, Timothy (2005). Political Selection. Journal of Economic Perspectives 19(3): 43-60.

Besley, Timothy (2006). Principled Agents? The Political Economy of Good Government. Oxford: Oxford University Press. 
Braendle, Thomas and Alois Stutzer (2010). Public Servants in Parliament: Theory and Evidence on Its Determinants in Germany. Public Choice 145(1): 223-252.

Braendle, Thomas and Alois Stutzer (2011). Selection of Public Servants into Politics. WWZ Discussion Paper 06/11.

Bruno, Giovanni S. F. (2005). Approximating the Bias of the LSDV Estimator for Dynamic Panel Data Model. Economics Letters 87(3): 361-366.

Calvert, Randy, Mathew McCubbins and Barry R. Weingast (1989). A Theory of Political Control and Agency Discretion. American Journal of Political Science 33(3): 588-611.

Caselli, Francesco and Massimo Morelli (2004). Bad Politicians. Journal of Public Economics 88(3-4): 759-782.

Chattopadhyay, Raghabendra and Esther Duflo (2004). Women as Policy Makers: Evidence from a Randomized Policy Experiment in India. Econometrica 72(5): 1409-1443.

Diermeier, Daniel, Michael Keane and Antonio Merlo (2005). A Political Economy Model of Congressional Careers. American Economic Review 95(1): 347-373.

Ferejohn, John and Keith Krehbiel (1987). The Budget Process and the Size of the Budget. American Political Science Review 31(2): 296-320.

Frank, Sue A. and Gregory B. Lewis (2004). Government Employees: Working Hard or Hardly Working? American Review of Public Administration 34(1): 36-51.

Gagliarducci, Stefano and Tommaso Nannicini (2012). Do Better Paid Politicians Perform Better? Disentangling Incentives from Selection. Forthcoming in the Journal of the European Economic Association.

Gagliarducci, Stefano, Tommaso Nannicini and Paolo Naticchioni (2011). Electoral Rules and Politicians' Behavior: A Micro Test. American Economic Journal: Economic Policy 3(3): 144-174.

Gagliarducci, Stefano, Tommaso Nannicini and Paolo Naticchioni (2010). Moonlighting Politicians. Journal of Public Economics 94(9-10): 688-699.

Galasso, Vincenzo and Tommaso Nannicini (2011). Competing on Good Politicians. American Political Science Review 105(1): 79-99.

Grant, J. Tobin and Nathan J. Kelly (2008). Legislative Productivity of the U.S. Congress, 1789-2004. Political Analysis 16(3): 303-323. 
Grossman, Gene M. and Elhanan Helpman (2008). Separation of Powers and the Budget Process. Journal of Public Economics 92(3-4): 407-425.

Holtmann, Everhard and Werner J. Patzelt (2004). Kampf der Gewalten. Wiesbaden: VS Verlag für Sozialwissenschaften.

Kalke, Jens and Peter Raschke (2004). Regierungsmehrheit und Opposition in den bundesdeutschen Landtagen - eine quantitative Auswertung von Plenarprotokollen. In: Everhard Holtmann and Werner J. Patzelt (eds.). Kampf der Gewalten. Wiesbaden: VS Verlag für Sozialwissenschaften: 85-106.

Kézdi, Gábor (2004). Robust Standard Error Esimation In Fixed-Effects Panel Models. Hungarian Statistical Review Special English Volume 9: 95-116.

Kennedy, Peter E. (1981). Estimation with Correctly Interpreted Dummy Variables in Semilogarithmic Equations. American Economic Review 71(4): 801.

Kerns, Peggy and Luke Martel (2008). Dual Employment: Regulating Public Sector Jobs for Legislators. Legisbrief 16(10). Washington: National Conference of State Legislatures.

Kintz, Melanie (2010). Die Berufsstruktur der Abgeordneten des 17. Deutschen Bundestages. Zeitschrift für Parlamentsfragen 41(3): 491-503.

Le Grand, Julian (2003). Motivation, Agency and Public Policy. Of Knights and Knaves, Pawns and Queens. Oxford: Oxford University Press.

Manow, Philip and Philipp Wettengel (2006). Ämterpatronage in der leitenden Ministerialbürokratie der Länder. Eine empirische Untersuchung der Stellenveränderungen vor und nach Landtagswahlen. Die Verwaltung 39(4): 553-570.

Massicotte, Louis (2003). To Create or To Copy? Electoral Systems in the German Laender. German Politics 12(1): 1-22.

McCubbins, Mathew, Roger Noll and Barry R. Weingast (1987). Administrative Procedures as Instruments of Political Control. Journal of Law, Economics, and Organization 3(2): 243-277.

Merlo, Antonio, Vincenzo Galasso, Massimiliano Landi and Andrea Mattozzi (2010). The Labor Market of Italian Politicians. In: Tito Boeri, Antonio Merlo and Andrea Prat (eds.). The Ruling Class: Management and Politics in Modern Italy. Oxford University Press: 9-107. 
Mielke, Siegfried and Werner Reutter (2004). Länderparlamentarismus in Deutschland. Wiesbaden: VS Verlag für Sozialwissenschaften.

Moe, Terry M. (1989). The Politics of Bureaucratic Structure. In: John Chubb and Paul Peterson (eds.). Can the Government Govern? Washington: Brookings Institution: 267329.

Nickell, Stephen J. (1981). Biases in Dynamic Models with Fixed Effects Econometrica 49(6): $1417-1426$.

Niskanen, William A. Jr. (1971). Bureaucracy and Representative Government. Chicago: Aldine-Atherton.

Niskanen, William A. Jr. (1975). Bureaucrats and Politicians. Journal of Law and Economics 18(3): 617-643.

Ogul, Morris S. and Bert A. Rockman (1990). Overseeing Oversight: New Departures and Old Problems. Legislative Studies Quarterly 15(1): 5-24.

Padro i Miquel, Gerard and James M. Snyder (2006). Legislative Effectiveness and Legislative Careers. Legislative Studies Quarterly 31(3): 347-381.

Patzelt, Werner (2005). Parlamente und ihre Macht. Kategorien und Fallbeispiele institutioneller Analyse. Baden-Baden: Nomos.

Patzelt, Werner (2006). Länderparlamentarismus. In: Herbert Schneider and Hans-Georg Wehling (eds.). Landespolitik in Deutschland. Grundlagen-Strukturen-Arbeitsfelder. Wiesbaden: VS Verlag für Sozialwissenschaften: 108-129.

Persson, Torsten, Roland Gerard and Guido Tabellini (1997). Separation of Powers and Political Accountability. Quarterly Journal of Economics 112(4): 1163-1202.

Raschke, Peter and Jens Kalke (1994). Quantitative Analyse parlamentarischer Tätigkeiten der Landtage. Zeitschrift für Parlamentsfragen 25(1): 32-45.

Reutter, Werner (2008). Föderalismus, Parlamentarismus und Demokratie. Landesparlamente im Bundesstaat. Opladen and Farmington Hills: Verlag Barbara Budrich.

Rosenthal, Alan (1981). Legislative Behavior and Legislative Oversight. Legislative Studies Quarterly 6(1): 115-131.

Russo, Federico and Matti Wiberg. (2010). Parliamentary Questioning in 17 European Parliaments: Some Steps towards Comparison. The Journal of Legislative Studies 16(2): 215-232. 
Schäfer, Markus (2005). Datenhandbuch zur Geschichte des Landtags Rheinland-Pfalz 19472003. Mainz: Hase \& Koehler.

Schindler, Peter (1999). Datenhandbuch zur Geschichte des Deutschen Bundestages 1949-1999. Baden-Baden: Nomos.

Schrode, Klaus (1977). Beamtenabgeordnete in Landtagen der Bundesrepublik Deutschland. Heidelberg: Carl Winter Universitätsverlag.

Shiller, Wendy J. (1995). Senators as Political Entrepreneurs: Using Bill Sponsorship to Shape Legislative Agendas. American Journal of Political Science 39(1): 186-203.

Snyder, James M. and Michael M. Ting (2002). An Informational Rationale for Political Parties. American Journal of Political Science 46(1): 90-110.

Volkshandbücher of the German Laender parliaments Baden-Württemberg, Bavaria, Berlin, Hesse, Rhineland-Palatinate, Saar, Schleswig-Holstein, North Rhine-Westphalia, Saxony, Lower Saxony, Bremen, Hamburg, Brandenburg, Saxony-Anhalt and Mecklenburg-LowerPomerania. Rheinbreitbach: Neue Darmstädter Verlagsanstalt.

van Aaken, Anne and Stefan Voigt (2011). Do Individual Disclosure Rules for Parliamentarians Improve Government Effectiveness? Economics of Governance 12(4): 301-324.

Weingast, Barry R. (1984). The Congressional-Bureaucratic System: A Principal Agent Perspective (with Applications to the SEC). Public Choice 44(1): 147-191.

Weingast, Barry R. and Mark Moran (1983). Bureaucratic Discretion or Congressional Control? Regulatory Policymaking by the Federal Trade Commission. Journal of Political Economy 91(5): 765-800.

Yamamoto, Hironori (2007). Tools for Parliamentary Oversight. A Comparative Study of 88 National Parliaments. Geneva: Inter-Parliamentary Union. 


\section{Figures and Tables}

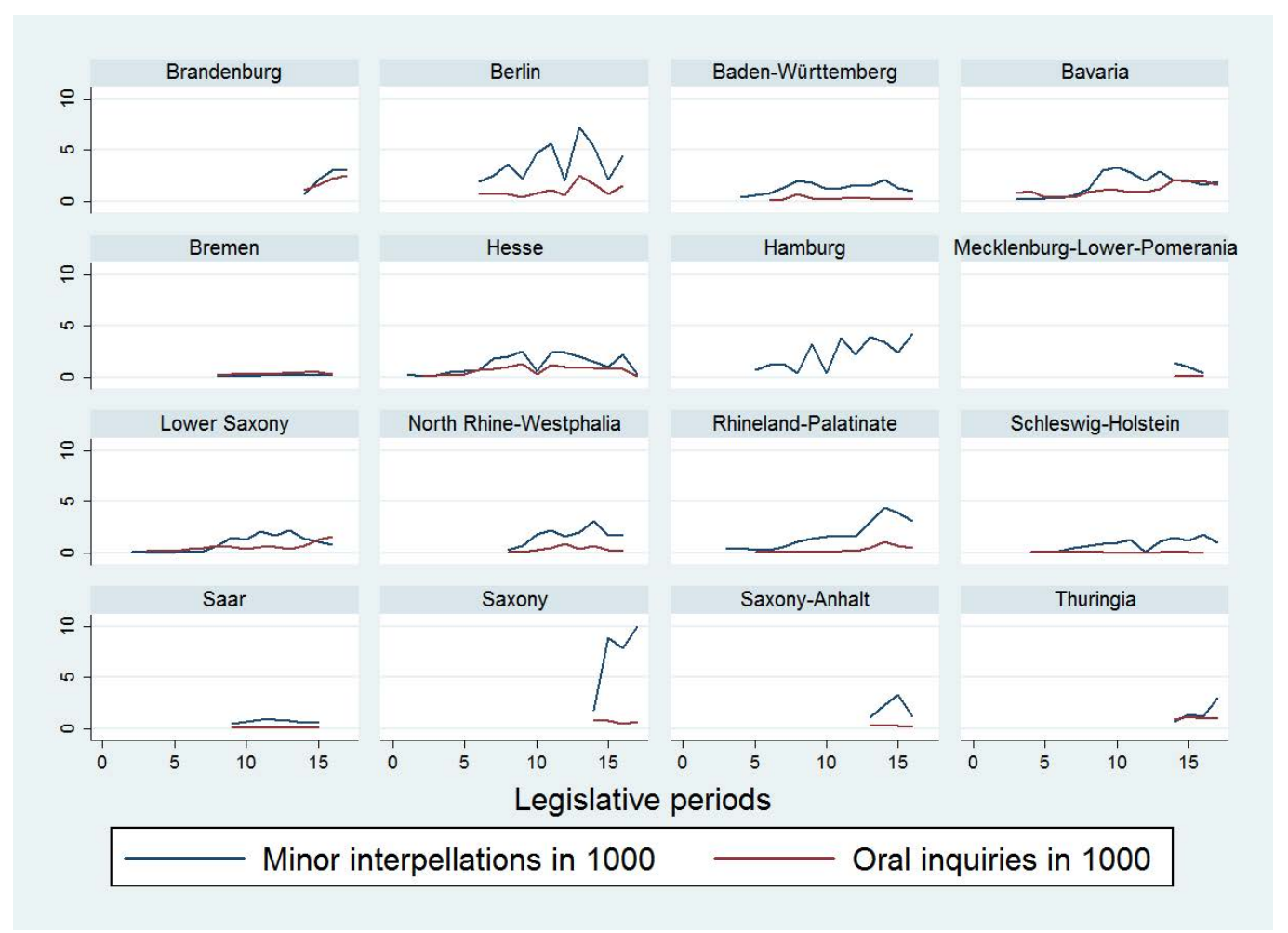

Figure 1: Use of Minor Interpellations and Oral Inquiries in German Laender Parliaments

Notes: The legislative periods are numbered backwards in order to obtain comparable timeseries. The $17^{\text {th }}$ legislative period always stands for the latest legislative period. The single observations are not standardized by the length of the respective legislative periods. The Hamburg parliament documentation service does not document the use of oral inquiries separately. In order to facilitate the comparability of the time-series, we restricted the maximal value to 10 (10.000 submissions of interpellations). This implies that the most recent observation for minor interpellations in Saxony is indicated with a value of 10 instead of 12,2.

Sources: See Table A.1. 


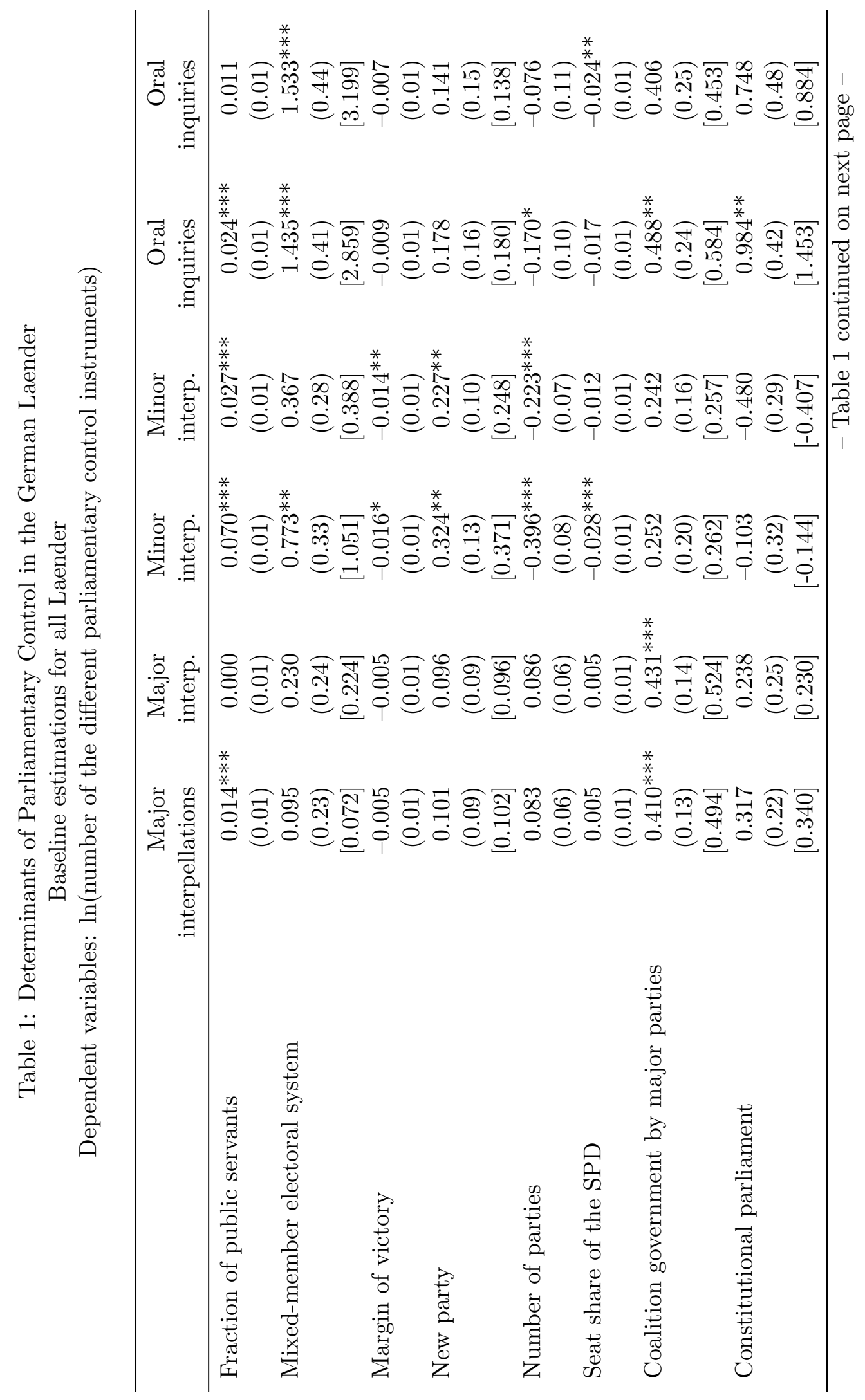




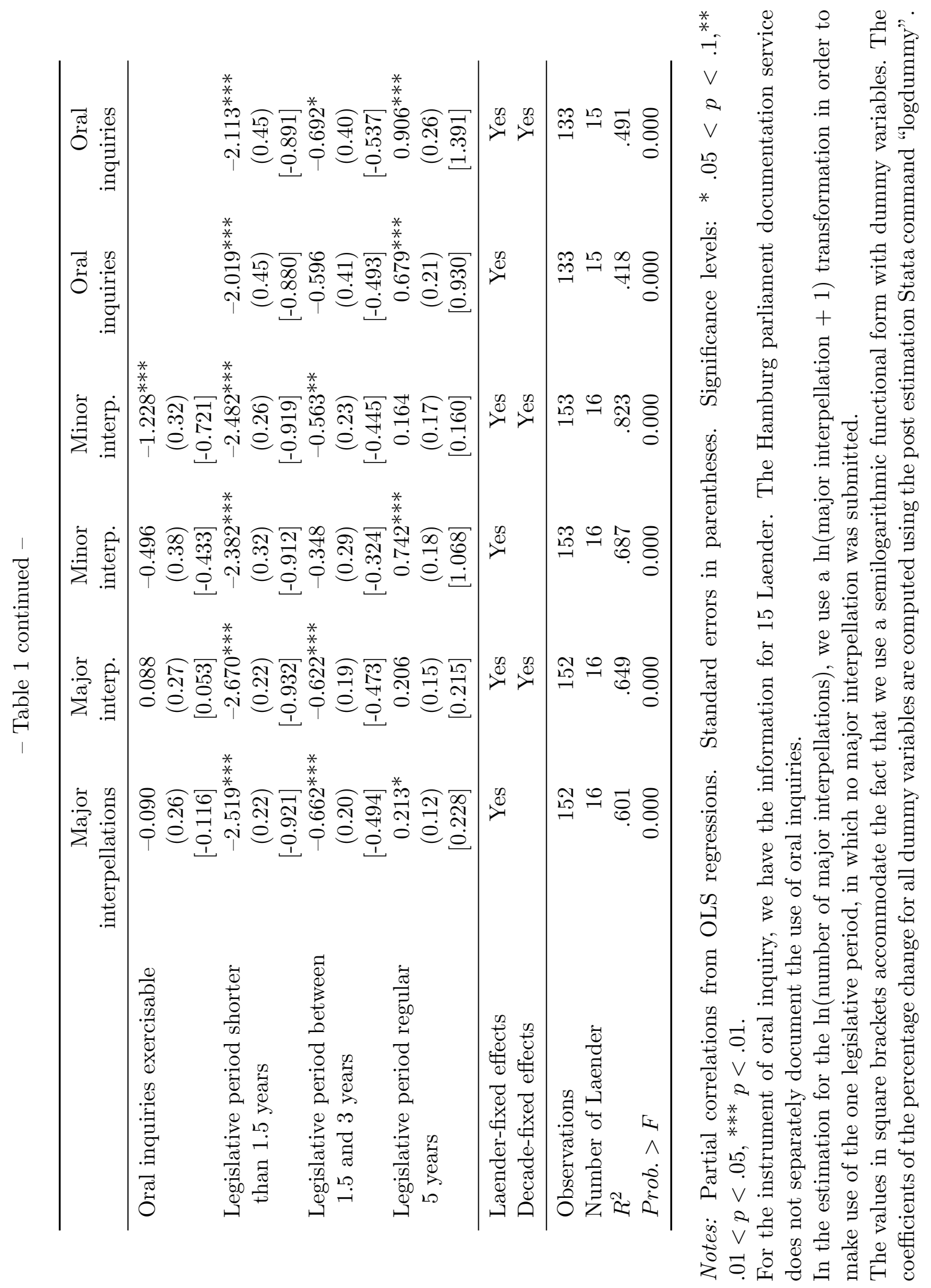




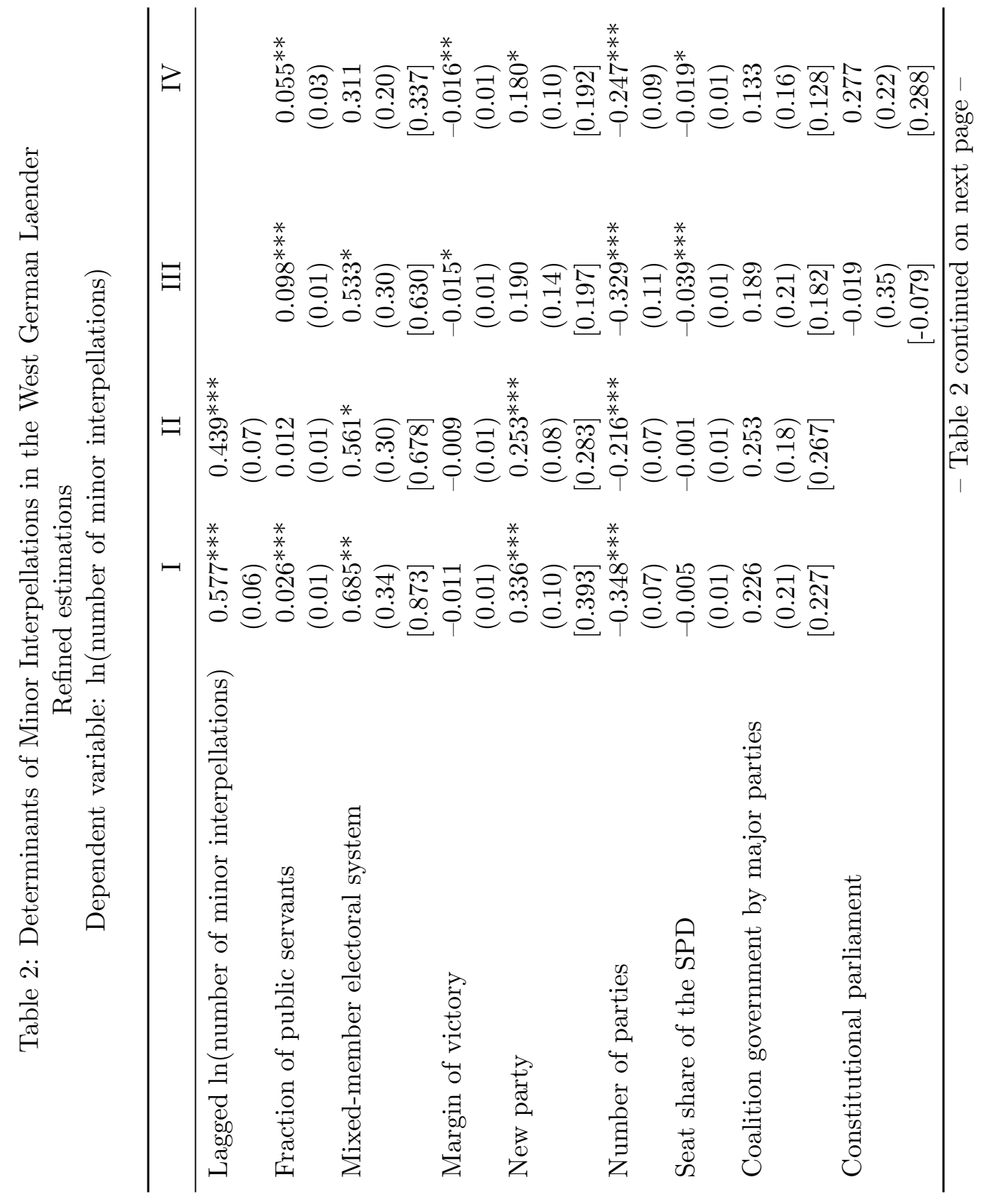




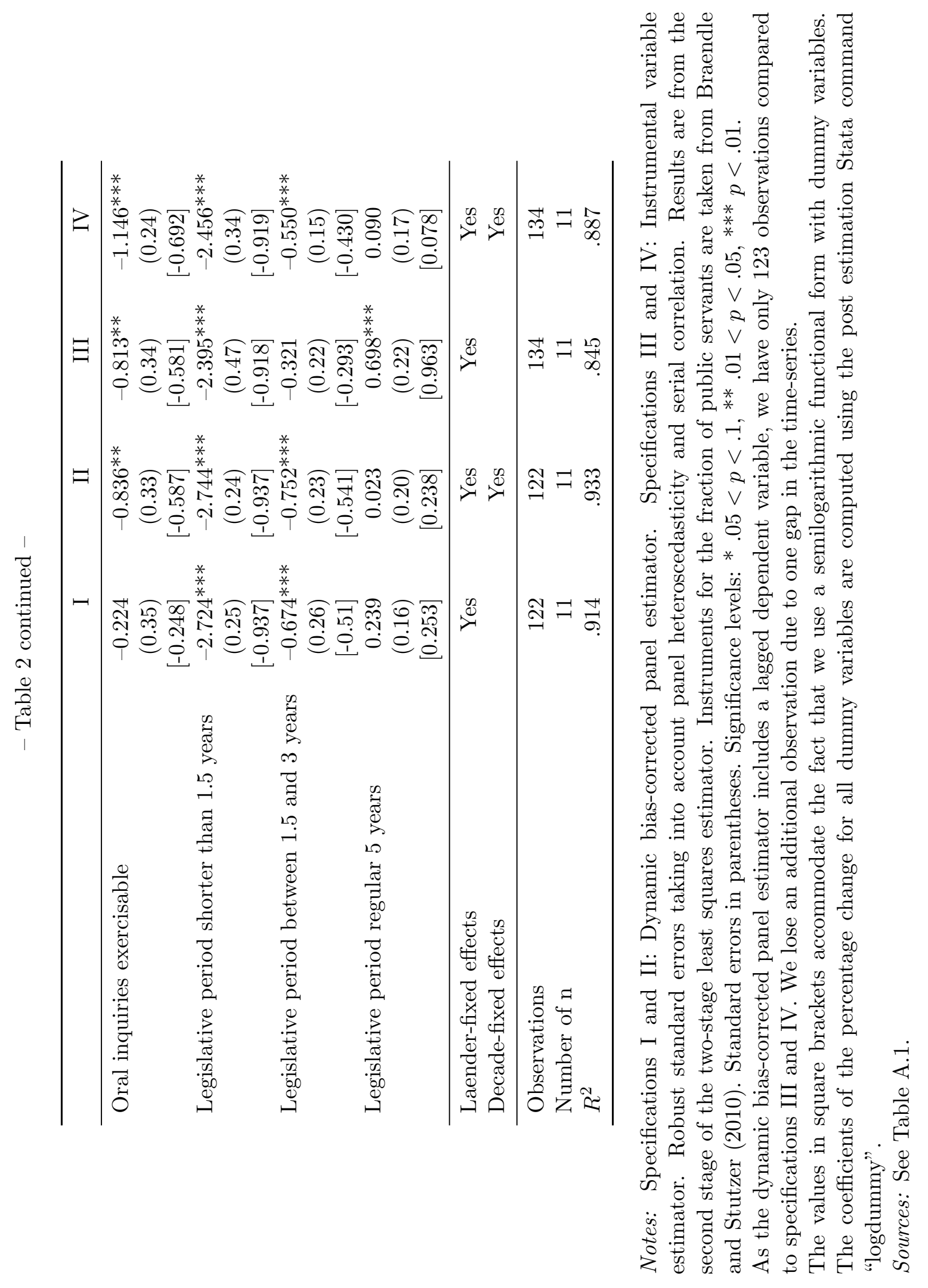




\section{Appendix}

Box A.1: Control Instruments in German Laender Parliaments

Major interpellation

Major interpellations (often called grosse Anfrage or Interpellation) are addressed to the government, are submitted in the form of a detailed written request to the president of the parliament, and have to be signed by a parliamentary group or by a minimum of five to fifteen legislators. In some Laender parliaments, one parliamentarian is the main supporter of the submission. The government is requested to provide a written reply within six weeks. After a reply is received, the interpellation is placed on the plenary agenda, and if the submitting group insists, a debate must take place. Prior to a debate, one of the questioners is allowed to present additional arguments backing the submitted interpellation. After the debate, parliamentarians can induce a motion for a resolution to express their opinion on the subject of the interpellation or the government's reply to it.

Minor interpellation

Minor interpellations (often called kleine or schriftliche Anfrage) are submitted by individual legislators in the form of a detailed written request containing up to ten specific questions. The government is expected to reply to the minor interpellation, in writing, within two weeks. The answer is published as parliamentary printed matter. If a minor interpellation is not answered in time, rules of procedure stipulate a transformation into a major interpellation.

Oral inquiry

They are also submitted by individual legislators in the form of a written request containing up to five specific questions. They must be sent some days before the next plenary debate takes place (previous notice). Their authors read them out and the government has to give an oral answer. Follow-up questions are allowed. The author is asked to express his or her (dis)satisfaction with the answer provided. If oral questions are not answered, the government has to deliver a written reply; otherwise, it is put forward to a minor interpellation. 
Box A.2: Example of a Minor Interpellation

The example of a minor interpellation is taken from the $4^{\text {th }}$ legislative period of the parliament of Mecklenburg-Lower-Pomerania. It was executed on November 26, 2003 (parliamentary printed matter 4/919). The interpellation was submitted by Harry Glawe, a member of parliament with a public service background.

Topic: Status of employee ill-health in the ministerial administration of Mecklenburg-LowerPomerania

1. The government ministries of Mecklenburg-Lower-Pomerania conduct a very different policy regarding the reporting of employee ill-health statistics. Are there particular reasons?

2. Do flexible vacation days influence the time structure of employee ill-health absences? Are the absences recorded, and if so, how detailed are the records?

3. How many members of staff are ill for more than six weeks (give as a percentage also)? Please give detailed information for each ministry. How has the number of absences of more than six weeks owing to ill-health developed over the past five years?

4. What is the annual average number of ill staff? What is the ratio of annually ill staff to annual working hours?

5. What criteria does the government apply in appraising the average level of staff ill in relation to the annual working hours?

6. What criteria does the government apply in appraising a comparison between the different ill-health statistics of the individual ministries?

7. How do these figures compare with parallel government institutions in other German regions?

Note: The example is not translated literally but with regard to content. See the working paper version for examples for major interpellations and oral inquiries.

Sources: Parliamentary online documentation services. 
Table A.1: Descriptive Statistics for the Dependent and Independent Variables

\begin{tabular}{|c|c|c|c|c|c|}
\hline & $\begin{array}{l}\text { Number } \\
\text { of LPs }\end{array}$ & Mean & Std. dev. & Min. & Max. \\
\hline \multicolumn{6}{|l|}{ Dependent variables } \\
\hline Major interpellations & 152 & 66.583 & 53.56 & 0 & 237 \\
\hline Minor interpellations & 153 & 1663.634 & 1723.853 & 7 & 12278 \\
\hline Oral inquiries & 133 & 545.871 & 546.931 & 3 & 2499 \\
\hline \multicolumn{6}{|l|}{ Continuous independent variables } \\
\hline Fraction of public servants & 153 & 40.481 & 10.363 & 10.6 & 61.6 \\
\hline Margin of victory & 153 & 11.799 & 8.858 & .1 & 41.5 \\
\hline Number of parties & 153 & 3.706 & .924 & 2 & 8 \\
\hline Seat share of the SPD & 153 & 40.794 & 9.806 & 10.484 & 62.162 \\
\hline Herfindahl party concentration index & 153 & 39.779 & 6.627 & 23.495 & 54.618 \\
\hline \multicolumn{6}{|l|}{ Independent variables coded as dummies } \\
\hline Mixed-member electoral system & 153 & .739 & .441 & 0 & 1 \\
\hline New party & 153 & .333 & .473 & 0 & 1 \\
\hline Coalition government by major parties & 153 & .144 & .352 & 0 & 1 \\
\hline Constitutional parliament & 153 & .059 & .236 & 0 & 1 \\
\hline Oral inquiries exercised & 153 & .346 & .477 & 0 & 1 \\
\hline Major alternation in government & 153 & .137 & .345 & 0 & 1 \\
\hline Coalition government & 153 & .595 & .493 & 0 & 1 \\
\hline Government led by the SPD & 153 & .477 & .501 & 0 & 1 \\
\hline LP shorter than 1.5 years & 153 & .033 & .178 & 0 & 1 \\
\hline LP lasting between 1.5 and 3 years & 153 & .039 & .195 & 0 & 1 \\
\hline LP lasting regular 4 years & 153 & .686 & .466 & 0 & 1 \\
\hline LP lasting regular 5 years & 153 & .242 & .430 & 0 & 1 \\
\hline
\end{tabular}

Notes: LP stands for legislative period. For independent variables that are coded as dummies, mean values indicate the fraction of observations that have the specific characteristic indicated by the label of the respective variable. The time series of minor interpellations for Hamburg also includes the number of oral inquiries submitted. The Hamburg parliament documentation service does not separately document the use of both instruments. However, the number of minor interpellation dominates the number of oral inquiries submitted.

Sources: For the dependent variables, see Kalke and Raschke (2004), Mielke and Reutter (2004), Raschke and Kalke (1994), Reutter (2008), Schäfer (2005), and various parliamentary handbooks and parliamentary documentation systems.

For the independent variables, see Braendle and Stutzer (2010) for the fraction of public servants, Massicotte (2003) for the coding of the variable electoral system, and Manow and Wettengel (2006) as well as the German electoral office (Bundeswahlleiter) for the coding of the form of government. For the coding of the variable capturing major alternation in government see Manow and Wettengel (2006) and the German electoral office (Bundeswahlleiter). For all other variables, the coding is based on information from the Bundes- or Landeswahlleiter. 
Table A.2: Descriptive Statistics for the Fraction of Public Servants Elected to German Laender Parliaments

\begin{tabular}{lccccc}
\hline & No. of LPs & Mean & Std. dev. & Min. & Max. \\
\hline Old Laender & & & & & \\
Baden-Württemberg & 13 & 47.21 & 9.45 & 29.00 & 61.60 \\
Bavaria & 15 & 40.45 & 9.91 & 23.80 & 53.43 \\
Berlin & 11 & 41.26 & 5.38 & 30.49 & 48.85 \\
Bremen & 7 & 37.16 & 5.31 & 30.12 & 45.00 \\
Hamburg & 12 & 33.74 & 5.06 & 23.14 & 41.66 \\
Hesse & 17 & 46.43 & 8.04 & 32.50 & 55.45 \\
Lower Saxony & 15 & 29.04 & 12.67 & 10.60 & 42.58 \\
North Rhine-Westphalia & 9 & 34.51 & 5.55 & 21.50 & 41.50 \\
Rhineland-Palatinate & 14 & 45.34 & 13.10 & 24.20 & 60.00 \\
Saar & 7 & 49.39 & 8.51 & 34.00 & 58.00 \\
Schleswig-Holstein & 14 & 43.34 & 8.25 & 24.60 & 58.10 \\
New Laender & & & & & \\
Brandenburg & 4 & 40.84 & 7.28 & 31.50 & 48.90 \\
Meckl.-Lower-Pomerania & 3 & 42.25 & 6.14 & 35.21 & 46.48 \\
Saxony & 4 & 44.45 & 6.48 & 35.48 & 50.80 \\
Saxony-Anhalt & 4 & 32.67 & 4.57 & 26.72 & 37.73 \\
Thuringia & 4 & 33.20 & 1.63 & 31.40 & 35.20 \\
\hline Sum old Laender & 134 & 40.76 & 10.74 & 10.6 & 61.60 \\
Sum new Laender & 19 & 38.50 & 7.02 & 26.72 & 50.80 \\
\hline Sum all Laender & 153 & 40.48 & 10.36 & 10.60 & 61.60 \\
\hline
\end{tabular}

Note: LPs indicates the number of legislative periods.

Sources: Braendle and Stutzer (2010). 
Table A.3: Electoral Rules Applied in the German Laender

\begin{tabular}{|c|c|c|}
\hline & Mixed-member system & Proportional representation \\
\hline \multicolumn{3}{|l|}{ Old Laender } \\
\hline Baden-Württemberg & as of LP 1 (1952) & never applied to observed periods \\
\hline Bavaria & as of LP 2 (1950) & LP 1 (1946-1950) \\
\hline Berlin & $\begin{array}{l}\text { applies to all observed periods } \\
\text { (as of 1967) }\end{array}$ & never applied to observed periods \\
\hline Bremen & never applied to observed periods & $\begin{array}{l}\text { applies to all observed periods } \\
\text { (as of 1971) }\end{array}$ \\
\hline Hamburg & never applied to observed periods & $\begin{array}{l}\text { applies to all observed periods } \\
\text { (as of 1970) }\end{array}$ \\
\hline Hesse & as of LP 3 (1954) & LP 1 - LP 2 (1946-1954) \\
\hline Lower Saxony & as of LP 1 (1947) & never applied to observed periods \\
\hline $\begin{array}{l}\text { North Rhine- } \\
\text { Westphalia }\end{array}$ & $\begin{array}{l}\text { applies to all observed periods } \\
\text { (as of 1962) }\end{array}$ & never applied to observed periods \\
\hline Rhineland-Palatinate & as of LP 12 (1991) & LP 1 - LP 11 (1947-1991) \\
\hline Saar & never applied to observed periods & $\begin{array}{l}\text { applies to all observed periods } \\
(1965-1999)\end{array}$ \\
\hline Schleswig-Holstein & as of LP 3 (1954) & never applied to observed periods \\
\hline \multicolumn{3}{|l|}{ New Laender } \\
\hline Brandenburg & as of LP 1 (1990) & never applied to observed periods \\
\hline $\begin{array}{l}\text { Meckl.-Lower- } \\
\text { Pomerania }\end{array}$ & $\begin{array}{l}\text { applies to all observed periods } \\
\text { (as of 1994) }\end{array}$ & never applied to observed periods \\
\hline Saxony & as of LP $1(1990)$ & never applied to observed periods \\
\hline Saxony-Anhalt & as of LP 1 (1990) & never applied to observed periods \\
\hline Thuringia & as of LP $1(1990)$ & never applied to observed periods \\
\hline
\end{tabular}

Notes: LP stands for legislative period. The table covers the electoral rules in place for the legislative periods for which we have the information on the execution of interpellation rights. Sources: Massicotte (2003) and the German electoral office (Bundeswahlleiter). 


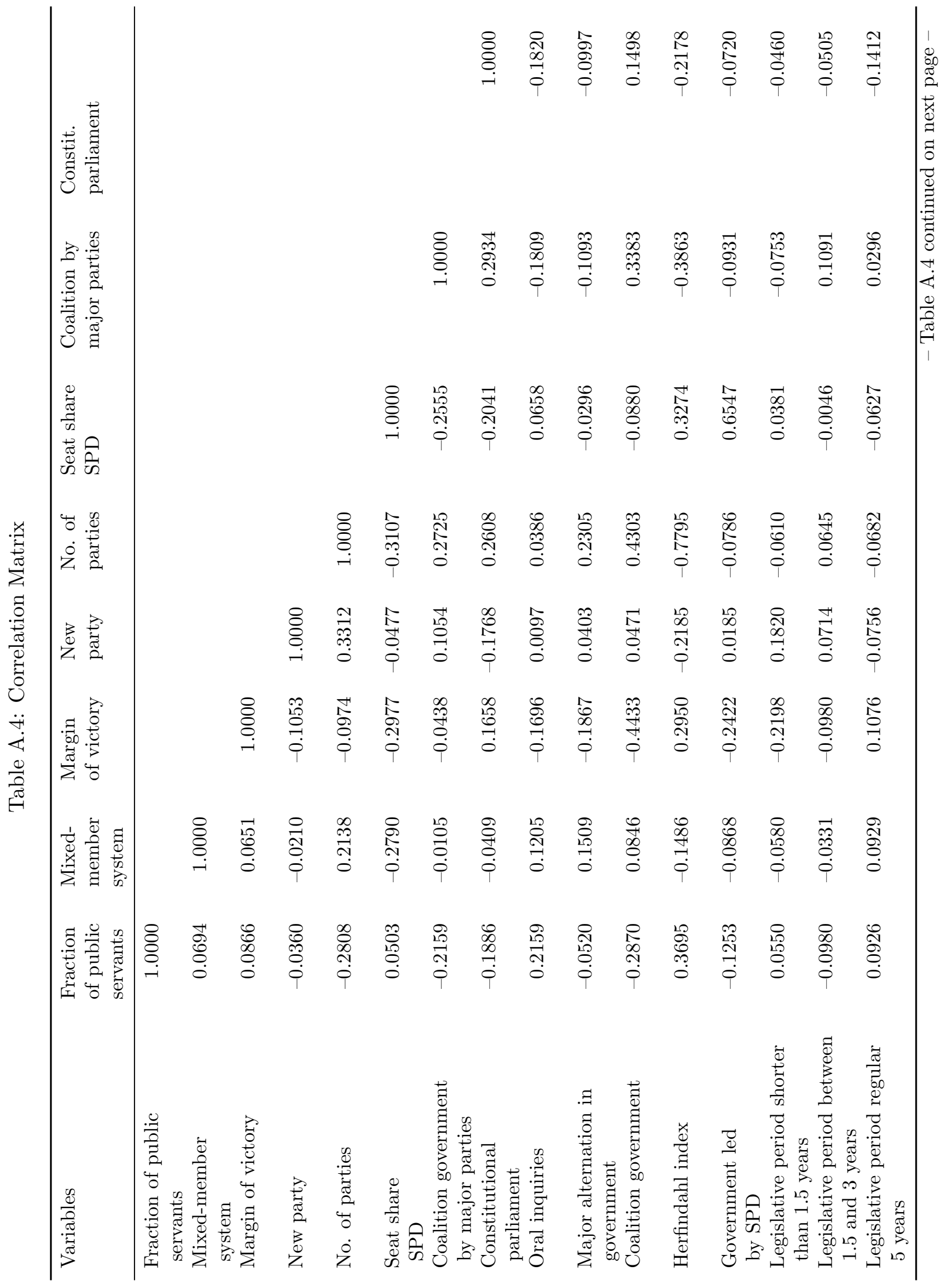




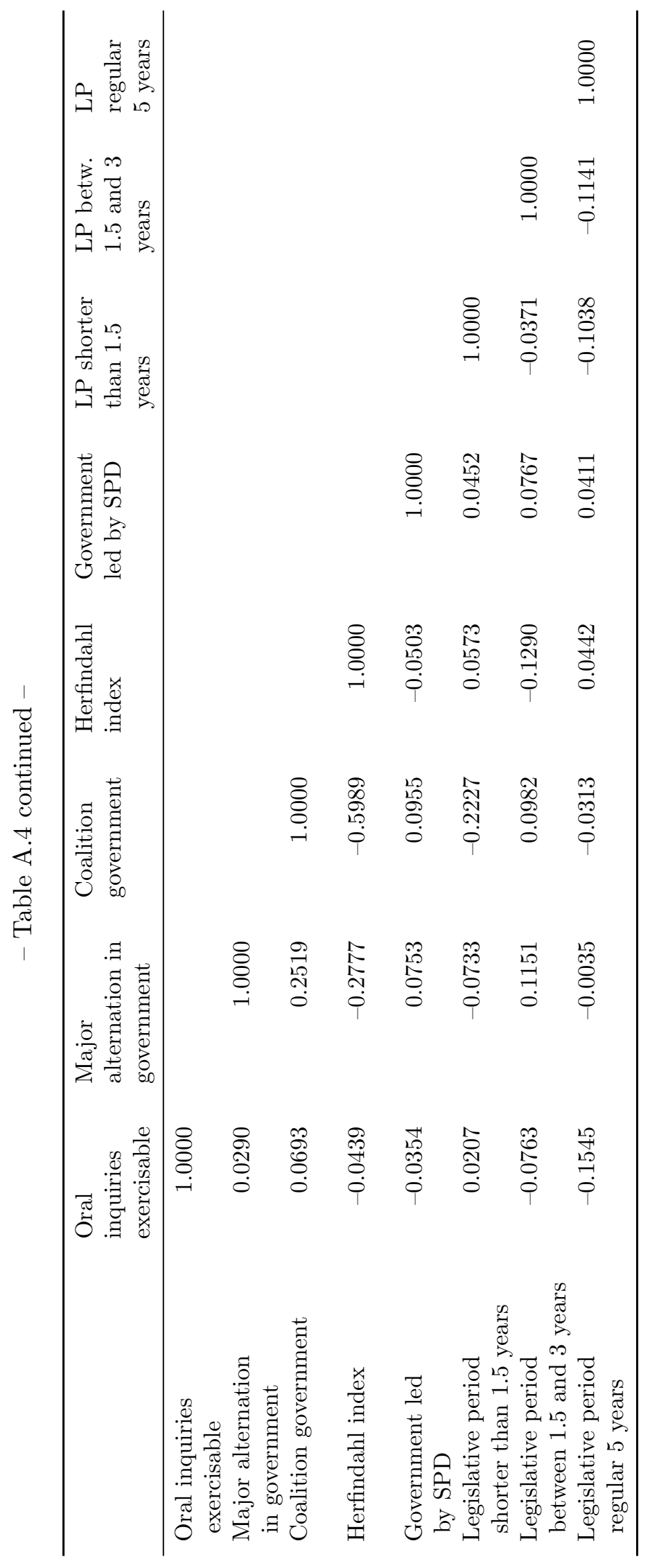




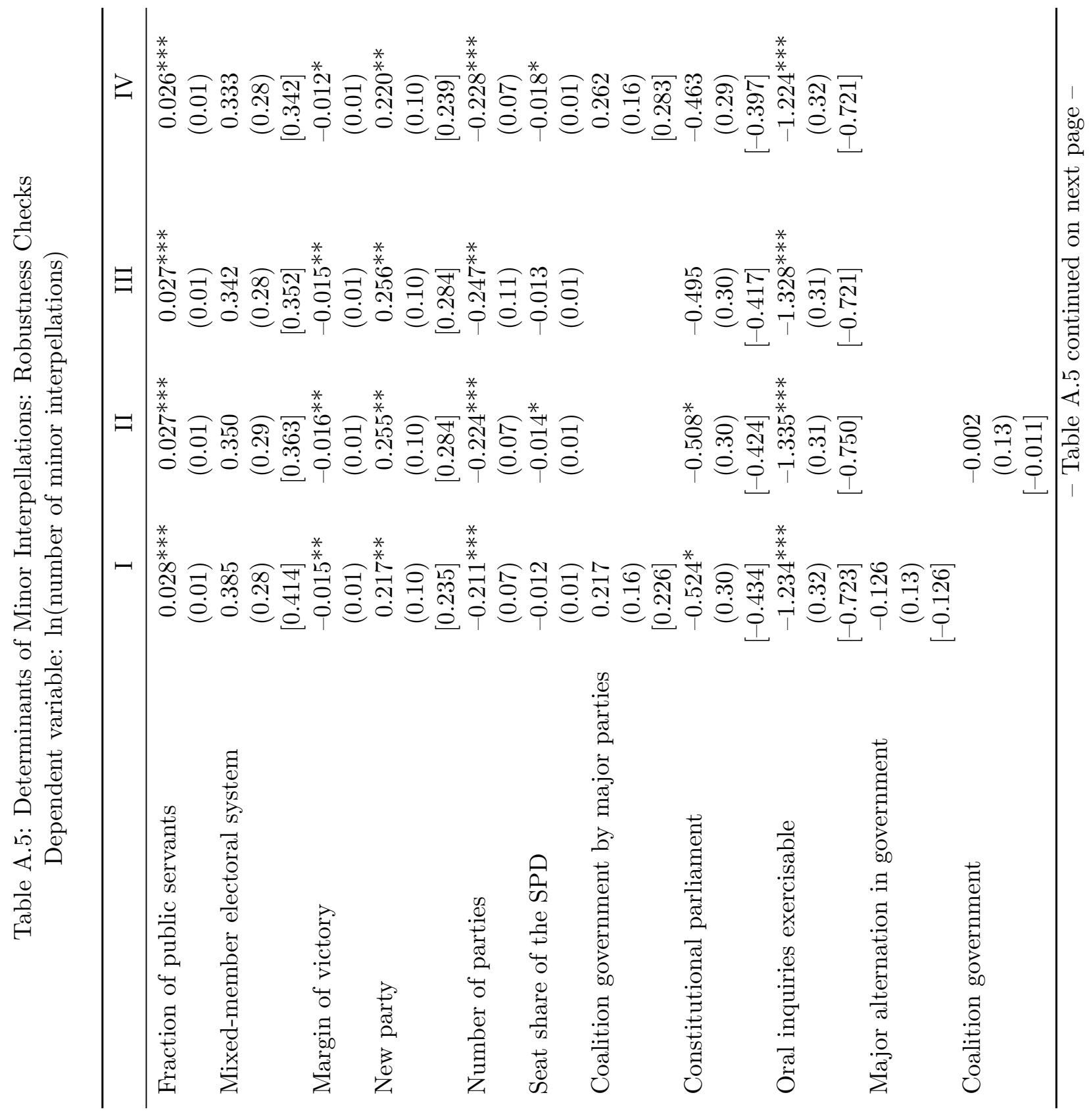




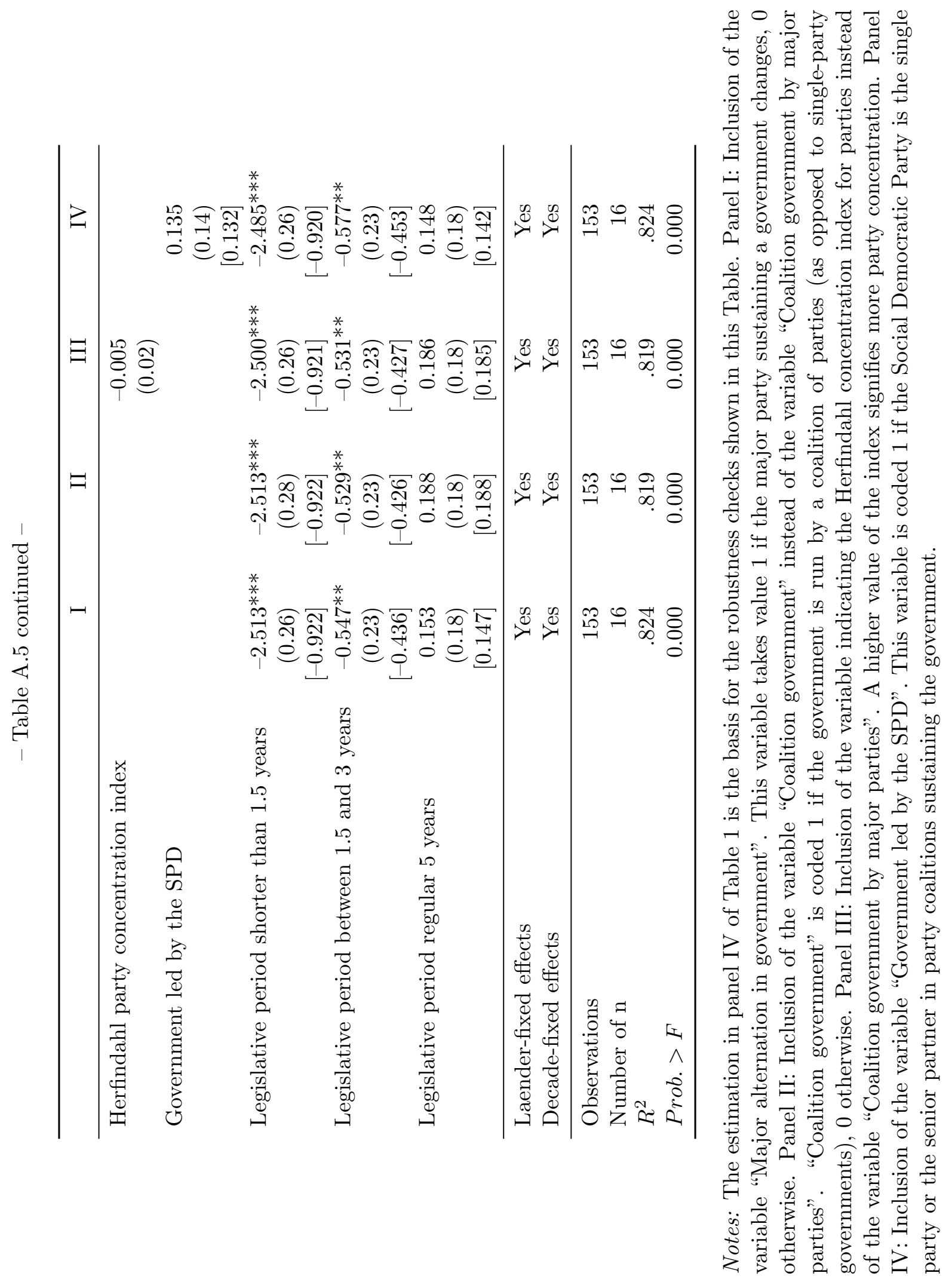

